Fils View/Frint Document Cover Sheet tow

This document was retrieved from the Documentation and Records Manaqement (DRM) ISEARCH System. It is intended for Information only and may not be the most recent or updated version. Contact a Document Service Center (see Hanford Info for locations) if you need additional retrieval information.

Accession \#: D196093645

Document \#: SD-TP-PDC-030

Title/Desc:

PACKAGING DESIGN CRITERIA FOR THE MCO CASK

Pages: 62 


\begin{tabular}{|c|c|c|c|c|c|c|}
\hline \multirow{3}{*}{$\begin{array}{l}\text { 2. ECN Category } \\
\text { (mark one) } \\
\\
\text { Supplemental } \\
\text { Direct Revision } \\
\text { Change ECN } \\
\text { Temporary } \\
\text { Standby } \\
\text { Supersedure } \\
\text { Cancel/Void }\end{array}$} & \multirow{3}{*}{$\begin{array}{r}{[]} \\
{[\times]} \\
{[]} \\
{[]} \\
{[]} \\
{[]} \\
{[]}\end{array}$} & \multicolumn{2}{|c|}{$\begin{array}{l}\text { 3. Originator's Name, Organization, MSIN, } \\
\text { and Telephone No. } \\
\text { W. S. Edwards } / 84100 / G I-12 / \\
376-2522\end{array}$} & \multicolumn{2}{|c|}{$\begin{array}{l}\text { 3a. USQ Required? } \\
{[] \text { Yes }[X] \text { No }}\end{array}$} & $\begin{array}{l}\text { 4. Date } \\
03 / 28 / 96\end{array}$ \\
\hline & & \multicolumn{2}{|c|}{$\begin{array}{l}\text { 5. Project Title/No./Work Order No. } \\
\qquad \text { LFO } 37\end{array}$} & \multicolumn{2}{|c|}{$\begin{array}{l}\text { 6. Bldg./Sys./Fac. No. } \\
\text { NA }\end{array}$} & $\begin{array}{c}\text { 7. Approval Designator } \\
\mathrm{SQ} \\
\end{array}$ \\
\hline & & \multicolumn{2}{|c|}{$\begin{array}{l}\text { 8. Document Numbers Changed by this ECN } \\
\text { (includes sheet no. and rev.) } \\
\text { WHC-SD-TP-PDC-030, Rev. } 1\end{array}$} & \multicolumn{2}{|c|}{$\begin{array}{l}\text { 9. Related ECN No(s). } \\
\text { NA }\end{array}$} & $\begin{array}{l}\text { 10. Related PO No. } \\
\text { NA }\end{array}$ \\
\hline \multirow{2}{*}{\multicolumn{2}{|c|}{$\begin{array}{l}\text { 11a. Modification Work } \\
\text { [] Yes (fill out Blk. } \\
11 \mathrm{~b}) \\
{[X] \text { No (NA Blks. 11b, }} \\
11 c, 11 \mathrm{~d} \text { ) }\end{array}$}} & \multirow[t]{2}{*}{$\begin{array}{l}\text { 11b. Work Package } \\
\text { No. } \\
\text { NA }\end{array}$} & \multicolumn{2}{|c|}{$\begin{array}{l}\text { 11c. Modification Work Complete } \\
\text { NA }\end{array}$} & \multicolumn{2}{|c|}{$\begin{array}{l}\text { 11d. Restored to Original Condi- } \\
\text { tion (Temp. or Standby ECN only) } \\
\text { NA }\end{array}$} \\
\hline & & & \multicolumn{2}{|c|}{ Cog. Engineer Signature \& Date } & \multicolumn{2}{|c|}{ Cog. Engineer signature \& Date } \\
\hline
\end{tabular}

12. Description of Change

1. The neutron source term was updated to reflect a more current analytical model.

2. A table describing the energy distribution of the (alpha,n) neutron source was added.

3. The target for the normal condition of transport free drop was changed from an unyielding surface to a more typical Hanford Site surface.

4. Acceptable external cask contamination was changed from U.S. Department of

Transportation (DOT) limits to HSRCM-1, Hanford Site Radiological Control Manual,

Timits.

5. Fabrication criteria for the MCO was revised to remove the requirement for volumetric inspection of the MCO closure weld.

13a. Justification (mark one)

$\begin{array}{llllllll}\text { Criteria Change } & {[X]} & \text { Design Improvement } & \text { [] } & \text { Environmental } & \text { [] } & \text { Facility Deactivation } \\ \text { As-Found } & {[]} & \text { Facilitate Const } & \text { [] } & \text { Const. Error/Omission } & \text { [] } & \text { Design Error/Omission }\end{array}$

13b. Justification Details

1. The source term for the MCO Cask was updated based on a change to the official neutron source term (WHC memo 8M730-LLC-95-011Rl, dated November 16, 1995).

2. The table with energy distribution of the (alpha, $n$ ) neutrons came directly from the revision to the official neutron source term (WHC memo 8M730-LLC-95-011R1).

3. Changing the target surface for the normal condition of transport free drop makes that drop more realistic, and allows the SNF program to eliminate impact 1 imiters from the MCO Cask, which will reduce personnel exposure.

4. Changing contamination limits to Hanford Site limits is conservative, since the Hanford Site 1 imits are more restrictive than DOT limits.

See Continuation Sheet

14. Distribution (include name, MSIN, and no. of copies)

W. S. Edwards

$\mathrm{G} 1-12,1$

T. D. Merki ing

J. G. Field

G1-11, 1

W. J. Schl auder

W. D. Ga110

R3-85, 1

S. S. Shiraga

J. R. Green

Gl-11, 1

R. J. Smith

GI-11, 1

D. W. McNal7y

R3-86, 1 Central Files
R3-09, 1

S7-84, 1

G1-11, 1

G1-11, 1

G1-11, 1

A3-88, 1

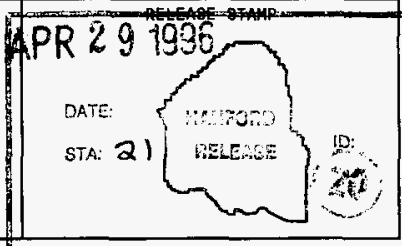

DATE:

A. T. Kee 


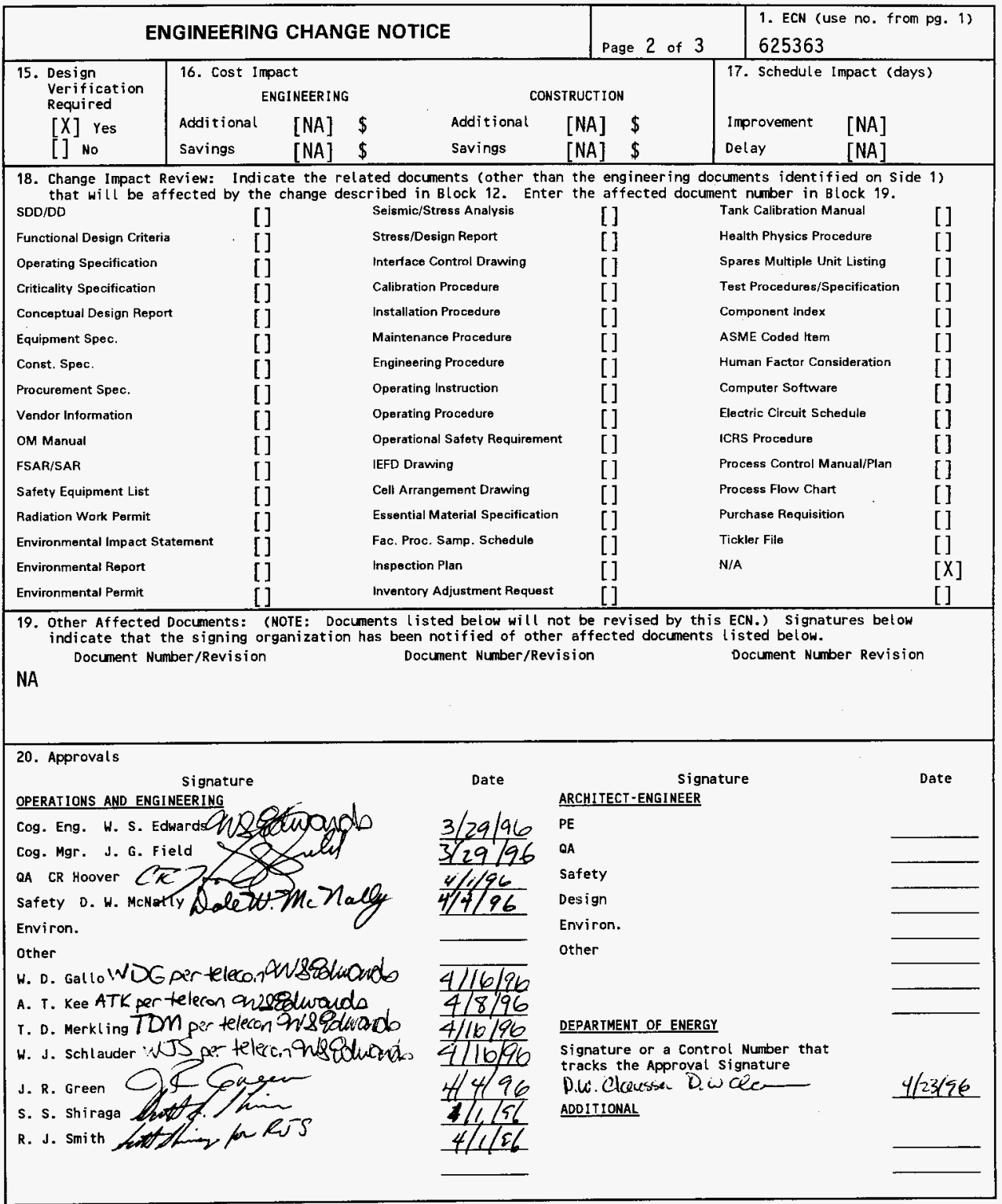


No. 13b. Cont inued

5. Only requiring surface inspections of the MCO closure weld is acceptable since the design analyses will not take credit for the portions of the weld that cannot be examined.

Design Verification of this change was performed and the changes were found not to adversely impact the underlying safety bases and parameters of the package. Nuclear verification was performed by J. R. Green. Structural/mechanical verification was performed by S. S. Shiraga. 


\title{
Packaging Design Criteria for the MCO Cask
}

\author{
W. S. Edwards
}

Westinghouse Hanford Company, Richland, WA 99352

U.S. Department of Energy Contract DE-AC06-87RL10930

$\begin{array}{lll}\text { EDT/ECN: } & 625352 & \text { UC: } 513 \\ \text { Org Code: } 84100 & \text { Charge Code: LF017 } \\ \text { B\&R Code: } & 35 \text { EW31354 } & \text { Total Pages: } 57\end{array}$

Key Words: Multiple Canister Overpack (MCO), Cask, Fuel Elements, $\mathrm{K}$ Basins, Canister Storage Building (CSB), Packaging, Package, Cask

Abstract: Approximately 2,100 metric tons of unprocessed, irradiated nuclear fuel elements are presently stored in the K Basins. To permit cleanup of the $K$ Basins and fuel conditioning, the fuel will be transported from the $K$ Basins to a Canister Storage Building in the 200 East Area. The purpose of this packaging design criteria is to provide criteria for the design, fabrication, and use of a packaging system to transport the large quantities of irradiated nuclear fuel elements positioned within Multiple Canister Overpacks.

TRADEMARK DISCLAIMER. Reference herein to any specific comercial product, process, or service by trade name, trademark, manufacturer, or otherwise, does not necessarily constitute or imply its endorsement, recommendation, or favoring by the United States Government or any agency thereof or $i$ ts contractors or subcontractors.

Printed in the United States of America. To obtain copies of this document, contact: WHC/BCS Document Control Services, P.O. Box 1970, Mailstop H6-08, Richland WA 99352, Phone (509) 372-2420; Fax (509) 376-4989.
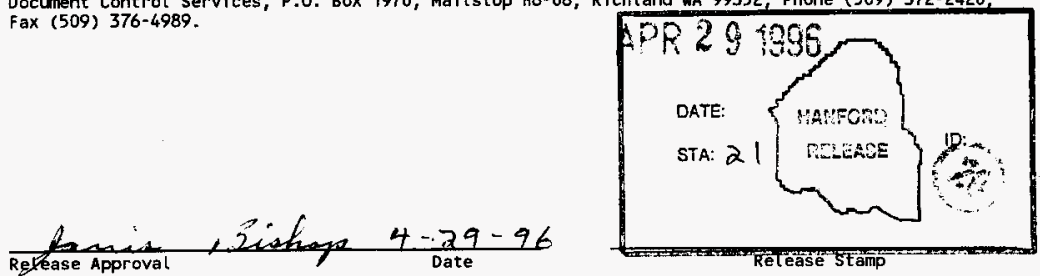

Approved for Public Release 


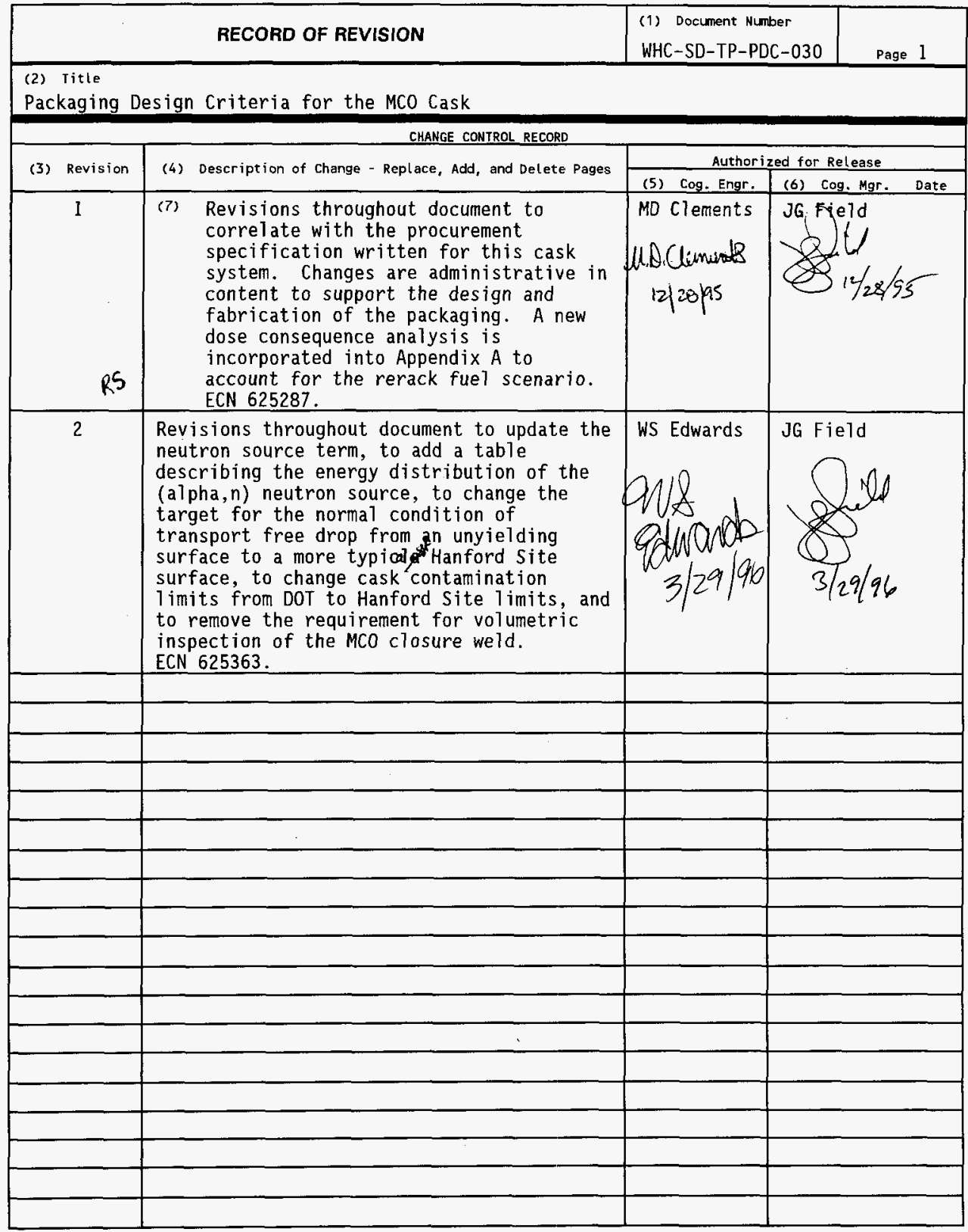




\section{CONTENTS}

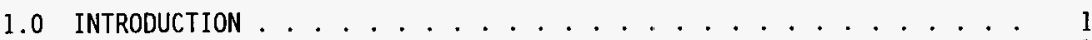

1.1 BACKGROUND . . . . . . . . . . . . . . . . . . . . 1

1.2 PURPOSE . . . . . . . . . . . . . . . 1

1.3 SYSTEM DESCRIPTION $\ldots \ldots \ldots$. . . . . . . . . . . . . . . . . .

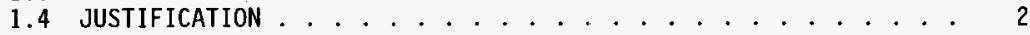

2.0 PACKAGE CONTENTS ..................... 2

2.1 PHYSICAL FORM .................. . . 2

$2.1 .1 \mathrm{MCOS} . \ldots . . . . . . . . . .22$

2.2 RADIOLOGICAL DESCRIPTION . . . . . . . . . . . 2

2.2.1 N Reactor Fuel . . . . . . . . . . . . . . . . 4

2.3 CHEMICAL CONSTITUENT SOURCE TERM ............. 7

2.4 GAS GENERATION ..................... . . 7

2.5 THERMAL DESCRIPTION ................. . . 8

2.5.1 Thermal Source Term . . . . . . . . . . 8

2.5.2 MCO Surface Emittance . . . . . . . . . . . . . 9 9

2.5.3 Payload and MCO Thermal Mass ............ . 9

2.5.4 MCO Dimensions and Gross Weight .......... . 9

2.5.5 Maximum MCO Temperature . . . . . . . . . . . . . 9

2.6 TRANSPORTATION CLASSIFICATION . . . . . . . . . . . . . 10

2.7 FISSILE CLASSIFICATION . . . . . . . . . . . . . . . . 10

2.8 CONTENT RESTRICTIONS ......................... 10

3.0 FACILITY OPERATIONS ............................ 11

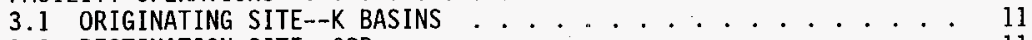

3.2 DESTINATION SITE--CSB . . . . . . . . . . . . . 11

4.0 PACKAGING/TRANSPORT SYSTEM DESIGN . . . . . . . . . . . 15

4.1 GENERAL . . . . . . . . . . . . . . . 15

4.2 PACKAGING DESIGN CRITERIA . . . . . . . . . . 15

4.2 .1 Packaging Materials . . . . . . . . . . . 15

4.2 .2 Fabrication Methods . . . . . . . . . . . 16

4.2.3 Packaging Dimensions .............. 16

4.2.4 Maximum Gross Weight .............. 16

4.2.5 Lifting and Tiedown Attachments .......... 17

4.2 .6 Venting ................... 17

4.2 .7 Loading . . . . . . . . . . . . . . 17

4.2 .8 Draining . . . . . . . . . . . . . 17

4.2 .9 Water Circulation . . . . . . . . . . . 17

4.2.10 Closure .................. . . 18

4.2.11 Containment ............... 18

4.2 .12 Shielding ................... 18

4.2.13 Maintenance . . . . . . . . . . . . 18

4.2.14 Life Cycle . . . . . . . . . . . . . . . 18

4.3 TRANSPORT SYSTEM . . . . . . . . . . . . . . . . . . . 19

4.3.1 General . . . . . . . . . . . . 19

4.3.2 Truck Transport System . . . . . . . . . . . . . . 19

4.3.3 Additional Requirements . . . . . . . . . 20

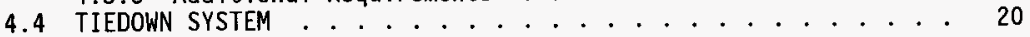


WHC-SD-TP-PDC-030 Rev. 2

CONTENTS (cont)

5.0 GENERAL REQUIREMENTS . . . . . . . . . . . . . . . 20

5.1 TRANSPORTATION SYSTEM . . . . . . . . . . . . . . 20

5.1.1 Normal Conditions of Transport . . . . . . . . . 20

5.1.2 Accident Conditions .............. . . 23

5.2 ALARA . . . . . . . . . . . . . . . . 25

5.3 QA . . . . . . . . . . . . . . 25

5.3.1 System Safety Class . . . . . . . . . . . 25

5.4 DESIGN FORMAT . . . . . . . . . . . . . . . . . . 26

5.5 ENVIRONMENTAL COMPLIANCE . . . . . . . . . . . . . . . . . . 26

5.6 MAINTENANCE . . . . . . . . . . . . . . . . . . . . . 26

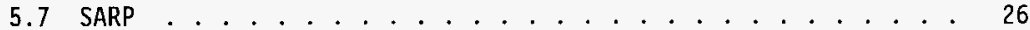

6.0 REFERENCES ......................... 26

\section{APPENDICES}

A SAFETY CLASSIFICATION FOR THE K BASIN CASK . . . . . . . . . . A-1

B ONSITE SARP TABLE OF CONTENTS .....................

\section{LIST OF FIGURES}

1 MCO Preliminary Design Description .............. 3

2 N Reactor Fuel Assembiy . . . . . . . . . . . . . . . . . 5

3 K Basin Layout ................... . . 12

$4 \mathrm{~K}$ Basin East and West Loadout Area ..... . . . . . . . . . . . . 13

5 Canister Storage Building Loadout Area . . . . . . . . . . . . . . . 14

\section{LIST OF TABLES}

1 Worst-Case Source Term for $\mathbf{N}$ Reactor Fue $1 . . . . . . . . . .44$

2 Photon Source: Mark IV Fue 1, $16 \%{ }^{240}$ Pu, 13 Years Decay . . . . . . 6

3 Energy Distribution of Neutrons from (alpha, $n$ ) Source . . . . . . 7

4 Heat Source Term . . . . . . . . . . . . . . . 8

5 Heat Source Term for Accident Conditions .............. 9

6 Preliminary Dimensions and Weight of the MCO .......... 10

7 External Cask Contamination Limits ............... 11

8 Load Factors for Tiedown Systems . . . . . . . . . . . . . . 20

9 Hanford Air Temperature . . . . . . . . . . . . . . 21

10 Maximum Solar Radiation Received from the Sun $\left(B T U / h-\mathrm{ft}^{2}\right)$. . . . 21 
WHC-SD-TP-PDC-030 Rev. 2

\section{LIST OF TERMS}

$\begin{array}{ll}\text { ALARA } & \text { as low as reasonably allowable } \\ \text { ANSI } & \text { American National Standards Institute } \\ \text { ARF } & \text { airborne release fraction } \\ \text { ASME } & \text { American Society of Mechanical Engineers } \\ \text { ASTM } & \text { American Society for Testing and Materials } \\ \text { CFR } & \text { Code of Federal Regulations } \\ \text { Ci } & \text { curie } \\ \text { CSB } & \text { Canister Storage Building } \\ \text { CVD } & \text { Cold Vacuum Drying } \\ \text { EDE } & \text { effective dose equivalent } \\ \text { g } & \text { gram } \\ \text { HRCQ } & \text { Highway Route Controlled Quantity } \\ \text { in. } & \text { inch } \\ \text { kg } & \text { kilogram } \\ \text { Km } & \text { kilometer } \\ \text { kPa } & \text { kilopascal } \\ \text { L/min } & \text { liters per minute } \\ \text { Ib } & \text { pound } \\ \text { m } & \text { meter } \\ \text { MCO } & \text { Multiple Canister Overpack } \\ \text { mR/h } & \text { milliroentgens per hour } \\ \text { mrem/h } & \text { millirems per hour } \\ \text { MTU } & \text { metric tons of uranium } \\ \text { oz } & \text { ounce } \\ \text { PDC } & \text { packaging design criteria } \\ \text { psi } & \text { pounds per square inch } \\ \text { QA } & \text { quality assurance } \\ \text { SARP } & \text { Safety Analysis Report for Packaging } \\ \text { SNF } & \text { spent nuclear fuel } \\ \text { SPR } & \text { Single Pass Reactor } \\ \mu \mathrm{m} & \text { micrometer } \\ \text { W } & \text { watt }\end{array}$


WHC-SD-TP-PDC-030 Rev. 2

This page intentionally left blank. 
WHC-SD-TP-PDC-030 Rev. 2

PACKAgING DESIGN CRITERIA FOR THE MCO CASK

\subsection{INTRODUCTION}

\subsection{BACKGROUND}

Approximately 2,100 metric tons of unprocessed, irradiated nuclear fuel elements are presently stored in the $\mathrm{K}$ Basins (including possibly 700 additional elements from PUREX, N Reactor, and 327 Laboratory). The basin water, particularly in the K East Basin, contains significant quantities of dissolved nuclear isotopes and radioactive fuel corrosion particles. To permit cleanup of the $\mathrm{K}$ Basins and fuel conditioning, the fuel will be transported from the $100 \mathrm{~K}$ Area to a Canister Storage Building (CSB) in the 200 East area. In order to initiate $\mathrm{K}$ Basin cleanup on schedule, the two-year fuel-shipping campaign must begin by December 1997.

\subsection{PURPOSE}

The purpose of this packaging design criteria (PDC) is to provide criteria for the design, fabrication, and use of a packaging system to transport large quantities of irradiated nuclear fuel elements positioned in Multiple Canister Overpacks (MCO), within the boundaries of the Hanford Site. The PDC will provide the basis for the system design and fabrication. It also sets the transportation safety criteria that the design will be evaluated against in the Safety Analys is Report for Packaging (SARP) (onsite). The approved PDC provides a formal set of standards early in the design and analytic process, and prevents costly delays later due to multiple and iterative interpretations of the requirements. The POC will be approved by Westinghouse Hanford Company, including Quality Assurance, Safety, the Safety and Environmental Advisory Counci1, and the U.S. Department of Energy, Richland Operations office.

\subsection{SYSTEM DESCRIPTION}

This packaging design criteria defines the requirements for the MCO cask and conveyance. The term "packaging" defines the cask without the MCO and fuel elements. The term "package" defines the cask, MCO, and the fuel elements. The MCO is the cask payload because it is loaded into and out of the cask and remains at the storage destination. The MCO provides a level of containment for the fuel elements. The MCO cask provides the transportation containment barrier for the payload, as defined in this PDC.

Fuel elements will be removed from their current canister storage containers in the $\mathrm{K}$ Basins, cleaned, and placed in baskets. The baskets will then be loaded into the MCO. The MCO may be top or bottom loaded into the cask. If the MCO is bottom loaded, there will be access to the top of the MCO for the cold vacuum drying process. Cold vacuum drying, which involves water 
WHC-SD-TP-PDC-030 Rev. 2

circulation and vacuum drying, is performed at the $\mathrm{K}$ Basins. After cold vacuum drying is complete, the MCO package is then transported to the CSB where further fuel conditioning and storage occur.

\subsection{JUSTIFICATION}

At present, no packagings licensed by either the U.S. Nuclear Regulatory Commission or the U.S. Department of Energy are capable of transporting the $\mathrm{K}$ Basins spent nuclear fuel (SNF) within the constraints of the project requirements. The project requires that the SNF be moved in MCOS. The only onsite packaging system that may be compatible is the three-wel1-railcar system, which is geometrically incompatible with the MCOs. A packaging and transportation system must be developed that can transport the irradiated fuel within current safety standards, protect the environment, and be economically and operationally feasible.

\subsection{PACKAGE CONTENTS}

\subsection{PHYSICAL FORM}

The payload will consist of an MCO that provides a level of containment for the irradiated fue 1 elements. MCOs are 61-cm (24-in. [outside diameter]) stainless steel pipe approximately $406 \mathrm{~cm}$ (160 in.) long, with the metallic uranium fuel elements in baskets stacked inside (Figure 1).

\section{$2.1 .1 \mathrm{MCOS}$}

The MCO will serve as a long-term storage vesset for the irradiated fuel elements, as well as the processing vessel during the conditioning process. For transport, the MCO is assumed to provide a level of containment. The MCO payload configuration is shown in Figure 1. The MCO will be drained and dried prior to shipment to the CSB.

\subsection{RADIOLOGICAL DESCRIPTION}

The irradiated fuel contains large quantities of fission products, such as ${ }^{137} \mathrm{Cs}$ and ${ }^{90} \mathrm{Sr}$, and actinides, such as ${ }^{239} \mathrm{Pu},{ }^{240} \mathrm{Pu}$, and ${ }^{241} \mathrm{Pu}$. To a lesser extent, it also contains cladding activation products, such as ${ }^{60} \mathrm{Co}$. A bounding worst-case radiological source term has been defined and is given in Table 1 . 
WHC-SD-TP-PDC-030 Rev. 2

Figure 1. MCO Preliminary Design Description.
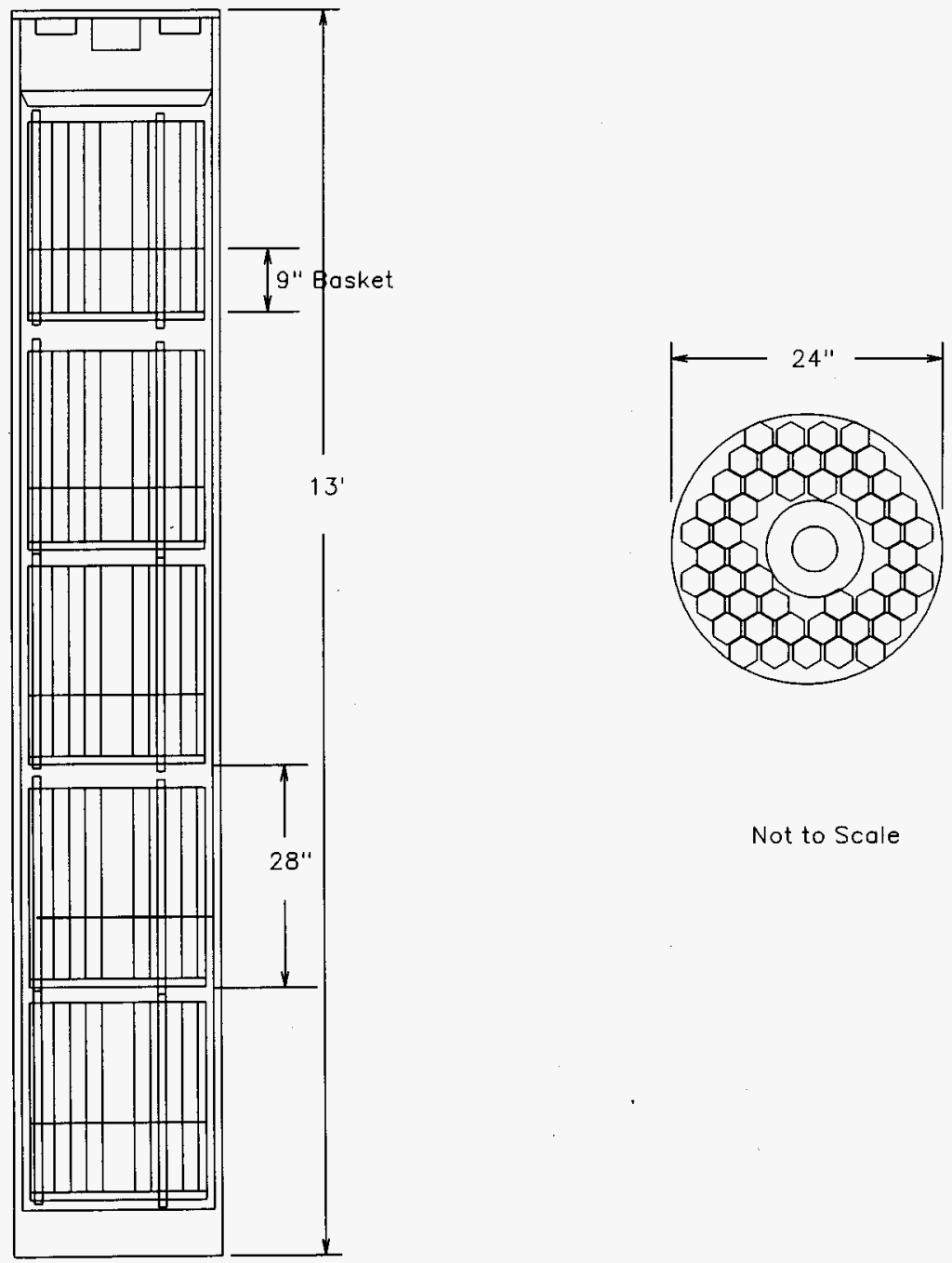

Not to Scale 


\subsubsection{N Reactor Fuel}

The bounding source term used for dose consequence is the rerack of 270 Mark IV fuel elements $66.3 \mathrm{~cm}$ (26.1 in.) long (E length [see Figure 2]). The worst anticipated N Reactor fue1, for shielding and dose consequence purposes, is $0.95 \%{ }^{235} \mathrm{U}$ fuel irradiated to $16 \%{ }^{240} \mathrm{Pu} 13$ years after discharge from the reactor at the time of first fuel shipment (12/31/97). Table 1 presents the anticipated worst-case activity per unit mass, per assembly, and per MCO (reracked fuel).

Table 1. Worst-Case Source Term for N Reactor Fuel.

\begin{tabular}{|c|c|c|c|c|c|c|c|}
\hline Isotope & $\begin{array}{l}\text { Curies } \\
\text { per MTU }\end{array}$ & $\begin{array}{l}\text { Curies per } \\
\text { single } \\
\text { assembly }\end{array}$ & $\begin{array}{l}\text { Curies per } \\
\text { MCO- }-270 \\
\text { assembl ies }\end{array}$ & I sotope & $\begin{array}{l}\text { Curies } \\
\text { per MTU }\end{array}$ & $\begin{array}{l}\text { Curies per } \\
\text { singte } \\
\text { assembly }\end{array}$ & $\begin{array}{l}\text { Curies per } \\
\text { MCO- -270 } \\
\text { assembl ies }\end{array}$ \\
\hline${ }^{3} \mathrm{H}$ & 38.8 & 0.91 & 246 & ${ }^{144} \mathrm{Ce}$ & 2.5 & 0.06 & 16 \\
\hline${ }^{55} \mathrm{Fe}$ & 6.8 & 0.16 & 43 & $144 \mathrm{Pr}$ & 2.5 & 0.06 & 16 \\
\hline${ }^{60} \mathrm{Co}$ & 160.9 & 3.78 & 1020 & ${ }^{147} \mathrm{Pm}$ & $2,423.2$ & 56.9 & 15,363 \\
\hline${ }^{85} \mathrm{Kr}$ & 611.5 & 14.36 & 3,877 & $151_{\mathrm{Sm}}$ & 102.7 & 2.41 & 651 \\
\hline${ }^{90} \mathrm{Sr}$ & $7,893.2$ & 185.34 & 50,043 & ${ }^{154} \mathrm{Eu}$ & 192.3 & 4.51 & 1219 \\
\hline${ }^{90} \mathrm{Y}$ & $7,893.2$ & 185.34 & 50,043 & ${ }^{155_{\mathrm{Eu}}}$ & 33.4 & 0.79 & 212 \\
\hline $106_{\mathrm{Ru}}$ & 11.5 & 0.27 & 73 & ${ }^{238} \mathrm{Pu}$ & 147.3 & 3.46 & 934 \\
\hline $106_{\mathrm{Rh}}$ & 11.5 & 0.27 & 73 & ${ }^{239} \mathrm{Pu}$ & 152.1 & 3.57 & 964 \\
\hline${ }^{125} \mathrm{sb}$ & 99.1 & 2.33 & 628 & $240 \mathrm{Pu}$ & 115 & 2.70 & 729 \\
\hline $125 \mathrm{~m}_{\mathrm{Te}}$ & 24.1 & 0.57 & 153 & $241_{\mathrm{Pu}}$ & $9,139.9$ & 214.62 & 57,947 \\
\hline${ }^{134} \mathrm{cs}$ & 115 & 2.70 & 729 & $241_{\mathrm{Am}}$ & 272.9 & 6.41 & 1730 \\
\hline${ }^{137} \mathrm{Cs}$ & $10,734.9$ & 252.07 & 68,059 & ${ }^{244} \mathrm{~cm}$ & 39.9 & 0.94 & 253 \\
\hline $137 \mathrm{~m}_{\mathrm{Ba}}$ & $10,162.3$ & 238.63 & 64,429 & & & & \\
\hline
\end{tabular}

MCO = Multiple Canister Overpack.

MTU = Metric tons of uraniufl. 


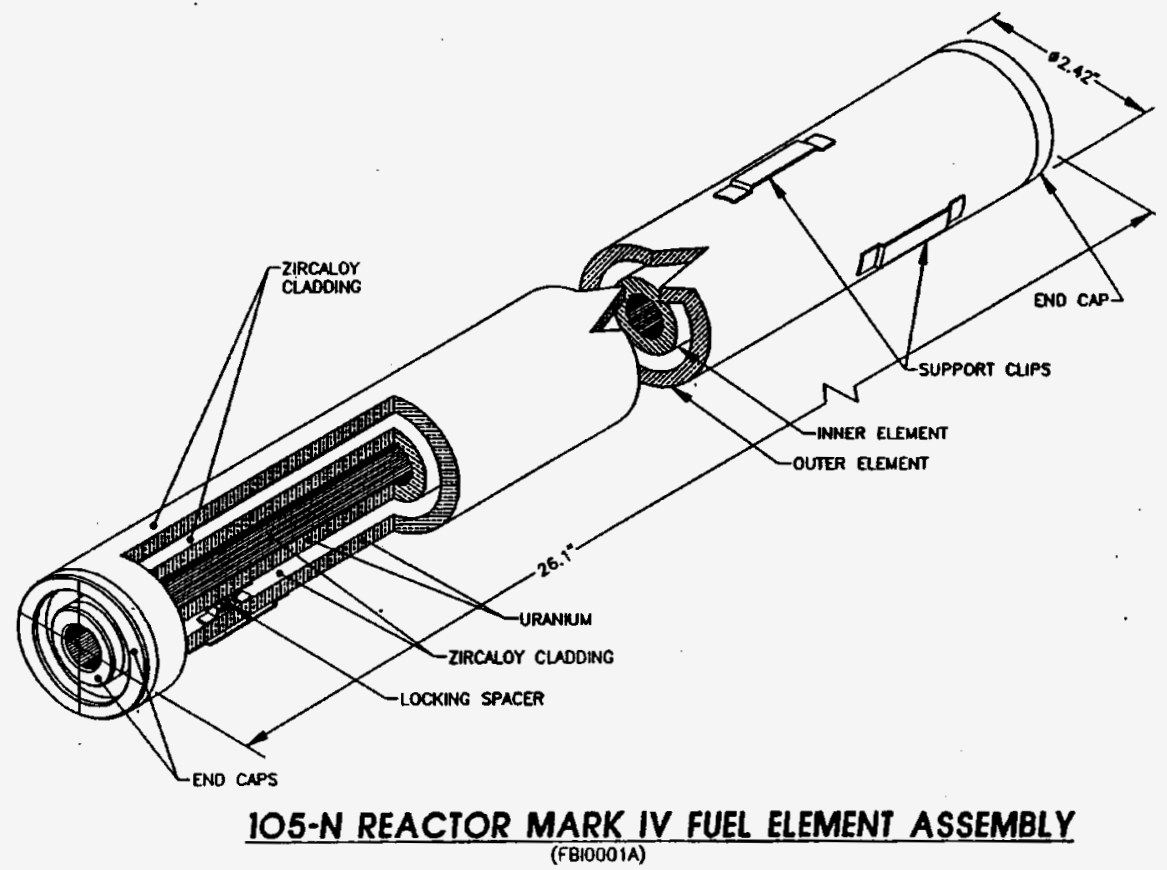


These isotopes have been used to calculate the gamma and neutron spectra generated in the fuel, as tabulated in Table 2 .

Table 2. Photon Source: Mark IV Fue 1, $16 \%{ }^{240} \mathrm{Pu}, 13$ Years Decay.

\begin{tabular}{|c|c|c|c|}
\hline Energy (MeV) & Photons/sec/element & Photons/sec/Mco & Photons/sec/MTU \\
\hline 0.015 & $5.845 \mathrm{E}+12$ & $1.578 E+15$ & $2.489 E+14$ \\
\hline 0.025 & $12.399 \mathrm{E}+11$ & $3.348 E+14$ & $5.280 E+13$ \\
\hline 0.038 & $13.951 \mathrm{E}+11$ & $3.767 E+14$ & $5.941 E+13$ \\
\hline 0.058 & $11.75 E+11$ & $3.174 E+14$ & $5.006 E+13$ \\
\hline 0.085 & $6.474 E+11$ & $1.748 \mathrm{E}+14$ & $2.757 E+13$ \\
\hline 0.125 & $4.799 \mathrm{E}+11$ & $1.296 \mathrm{E}+14$ & $2.044 E+13$ \\
\hline 0.225 & $5.480 E+11$ & $1.480 \mathrm{E}+14$ & $2.334 E+13$ \\
\hline 0.375 & $2.586 \mathrm{E}+11$ & $0.698 E+14$ & $1.101 \mathrm{E}+13$ \\
\hline 0.662 & $9.364 E+12$ & $2.568 \mathrm{E}+15$ & $3.988 E+14$ \\
\hline 0.850 & $20.309 E+10$ & $5.484 E+13$ & $8.649 \mathrm{E}+12$ \\
\hline 1.250 & $3.816 \mathrm{E}+11$ & $1.030 \mathrm{E}+14$ & $1.625 \mathrm{E}+13$ \\
\hline 1.750 & $3.578 E+9$ & $0.966 \mathrm{E}+12$ & $1.524 \mathrm{E}+11$ \\
\hline 2.250 & $3.299 \mathrm{E}+7$ & $0.872 \mathrm{E}+10$ & $1.375 E+09$ \\
\hline 2.750 & $21.798 \mathrm{E}+5$ & $5.885 E+8$ & $9.283 E+7$ \\
\hline 3.500 & $2.952 E+5$ & $0.797 \mathrm{E}+8$ & $1.257 E+7$ \\
\hline 5.000 & $6.338 E+3$ & $1.711 E+6$ & $2.699 E+5$ \\
\hline 7.000 & $7.294 \mathrm{E}+2$ & $1.969 \mathrm{E}+5$ & $3.106 \mathrm{E}+4$ \\
\hline 11.000 & $8.371 E+1$ & $2.260 \mathrm{E}+4$ & $3.565 E+3$ \\
\hline Total & $21.540 E+12$ & $5.816 E+15$ & $9.173 \mathrm{E}+14$ \\
\hline
\end{tabular}

MCO = Multiple Canister Overpack.

$\mathrm{MeV}=$ Megaelectronvolt.

MTU = Metric tons of uranium.

The following is the neutron source for Mark IV fuel $16 \%{ }^{240} \mathrm{Pu}$ at 13 years decay (Schwarz 1995).

- The spontaneous fission source is $8.732 E+05$ neutrons/sec/MTU, and the (alpha, $n$ ) neutron source is $4.861 \mathrm{E}+05$ neutrons/sec/MTU.

- The neutron energy spectrum for the spontaneous fission source is assumed to be that for ${ }^{244} \mathrm{Cm}$, a predominant nuclide contributing to spontaneous fission. That spectrum is given by the following:

$$
f(E)=C * \exp (-E / 0.906))^{\star} \sinh (\sqrt{3} .848 * E)
$$

$C$ is a normalization constant so that the integral is unity. 
- The neutron energy spectrum for the $(a) p h a, n)$ neutron source is given in Table 3 .

Table 3. Energy Distribution of Neutrons from (alpha, n) Source.

\begin{tabular}{|c|c|c|c|c|c|}
\hline $\begin{array}{c}\text { Upper energy } \\
(\mathrm{MeV})\end{array}$ & $\begin{array}{l}\text { Cumulat ive } \\
\text { probability }\end{array}$ & $\begin{array}{c}\text { Probability } \\
\text { of bin }\end{array}$ & $\begin{array}{c}\text { Upper energy } \\
\text { (MeV) }\end{array}$ & $\begin{array}{l}\text { Cumulat ive } \\
\text { probabil ity }\end{array}$ & $\begin{array}{c}\text { Probability } \\
\text { of bin }\end{array}$ \\
\hline 0.00 & 0.00000 & 0.00000 & 2.30 & 0.59751 & 0.04128 \\
\hline 0.10 & 0.01590 & 0.01059 & 2.40 & 0.63707 & 0.03956 \\
\hline 0.20 & 0.02243 & 0.01184 & 2.50 & 0.67492 & 0.03785 \\
\hline 0.30 & 0.03396 & 0.01153 & 2.60 & 0.71137 & 0.03645 \\
\hline 0.40 & 0.04766 & 0.01371 & 2.70 & 0.74611 & 0.03474 \\
\hline 0.50 & 0.06636 & 0.01869 & 2.80 & 0.77819 & 0.03209 \\
\hline 0.60 & 0.08738 & 0.02103 & 2.90 & 0.80935 & 0.03115 \\
\hline 0.70 & 0.11044 & 0.02305 & 3.00 & 0.83863 & 0.02928 \\
\hline 0.80 & 0.13567 & 0.02523 & 3.10 & 0.86449 & 0.02586 \\
\hline 0.90 & 0.15981 & 0.02414 & 3.20 & 0.88879 & 0.02430 \\
\hline 1.00 & 0.17975 & 0.01994 & 3.30 & 0.90966 & 0.02087 \\
\hline 1.10 & 0.20062 & 0.02087 & 3.40 & 0.92664 & 0.01698 \\
\hline 1.20 & 0.22321 & 0.02259 & 3.50 & 0.94097 & 0.01433 \\
\hline 1.30 & 0.24860 & 0.02539 & 3.60 & 0.95327 & 0.01231 \\
\hline 1.40 & 0.27601 & 0.02741 & 3.70 & 0.96324 & 0.00997 \\
\hline 1.50 & 0.30405 & 0.02804 & 3.80 & 0.97181 & 0.00857 \\
\hline 1.60 & 0.33349 & 0.02944 & 3.90 & 0.97928 & 0.00748 \\
\hline 1.70 & 0.36542 & 0.03193 & 4.00 & 0.98536 & 0.00607 \\
\hline 1.80 & 0.40093 & 0.03551 & 4.10 & 0.99081 & 0.00545 \\
\hline 1.90 & 0.43785 & 0.03692 & 4.20 & 0.99439 & 0.00358 \\
\hline 2.00 & 0.47664 & 0.03879 & 4.30 & 0.99720 & 0.00280 \\
\hline 2.10 & 0.51558 & 0.03894 & 4.40 & 0.99891 & 0.00171 \\
\hline 2.20 & 0.55623 & 0.04065 & $4: 50$ & 1.0000 & 0.00109 \\
\hline
\end{tabular}

\subsection{CHEMICAL CONSTITUENT SOURCE TERM}

The reracked fuel will be cold vacuum dried within the MCO prior to transport. There will be not greater than $2 \mathrm{~kg}$ of water remaining in the MCO following the cold vacuum drying operation.

\subsection{GAS GENERATION}

The packaging design shall incorporate features that will prevent the concentration of hydrogen gas in the cask annulus from exceeding $5 \%$ by volume 
during a period of time twice the maximum expected shipping time (NRC 1984). If hydrogen concentration in the $M C O$ is above the $5 \% 1 \mathrm{imit}$, appropriate administrative and safety precautions will be provided to meet onsite equivalent safety requirements.

\subsection{THERMAL DESCRIPTION}

The heat source term will vary according to the type, condition, and amount of SNF to be transported. For the purposes of this PDC, the thermal source term for the payload (fuel elements) within the MCO is defined as a surface heat flux at the boundaries of the MCO. In addition, the surface emittance, thermal mass, temperature limits, etc., to be assumed for the MCO and payload assembly are defined.

\subsubsection{Thermal Source Term}

2.5.1.1 Thermal Source Term for Normal Transport Conditions. The range of anticipated heat flux at the inside surfaces of the MCO under normal transport conditions is defined in Table 4. The defined sidewall surface heat flux occurs over the lower $3.51 \mathrm{~m}(11.5 \mathrm{ft})$ of the MCO.

Table 4. Heat Source Term for Normal Transport Conditions.

\begin{tabular}{|l|c|c|c|c|}
\hline Payload & $\begin{array}{c}\text { Surface heat } \\
\text { flux at MC0 } \\
\text { sidewalls }\end{array}$ & $\begin{array}{c}\text { Surface heat } \\
\text { flux at MCO top }\end{array}$ & $\begin{array}{c}\text { Surface heat } \\
\text { flux at MC0 } \\
\text { bottom }\end{array}$ & $\begin{array}{c}\text { Total watts } \\
\text { per MC0/cask }\end{array}$ \\
\hline Maximum--dry & $12.7 \mathrm{~W} / \mathrm{ft}^{2}$ & $5 \mathrm{~W} / \mathrm{ft}^{2}$ & $5 \mathrm{~W} / \mathrm{ft}^{2}$ & 950 \\
\hline Minimum & 0.00 & 0.00 & 0.00 & 0.00 \\
\hline
\end{tabular}

MCO = Multiple Canister Overpack.

2.5.1.2 Thermal Source Term for Accident Conditions. Due to possible chemical reaction of the SNF at elevated temperatures, the maximum surface heat flux will vary during the accident transport conditions from that defined for the normal transport conditions. This variation in surface heat flux at the inside boundaries of the MCO is defined in Table 5. The surface heat fluxes in Table 4 are to be used in establishing the steady-state conditions preceding the accident conditions.

The surface heat flux at the MCO top and bottom is the same as defined for the normal transport conditions. The variation in heat flux with location on the MCO circumference can be ignored during the accident transient. 


$$
\text { WHC-SD-TP-PDC-030 } \cdot \text { Rev. } 2
$$

Table 5. Heat Source Term for Accident Conditions.

\begin{tabular}{|l|c|c|c|}
\hline Payload & $\begin{array}{c}\text { Surface heat flux at } \\
\text { center 28-in. section } \\
\text { of MCO sidewall }\end{array}$ & $\begin{array}{c}\text { Surface heat flux at } \\
\text { remainder of MC0 } \\
\text { sidewall }\end{array}$ & $\begin{array}{c}\text { Total watts } \\
\text { per MC0 }\end{array}$ \\
\hline Maximum & $30.0 \mathrm{~W} / \mathrm{ft}^{2}$ & $12.7 \mathrm{~W} / \mathrm{ft}^{2}$ & 1200 \\
\hline Minimum & 0 & 0 & 0 \\
\hline
\end{tabular}

MCO = Multiple Canister Overpack.

\subsubsection{MCO Surface Emittance}

For the purpose of calculating radiative heat transfer between the MCO and the packaging system, the surface emittance of the MCO surfaces shall be assumed to be 0.25 .

\subsubsection{Payload and MCO Thermal Mass}

No credit for the thermal mass of the payload shall be taken when calculating the transient performance of the packaging system under either the normal conditions of transport or the accident conditions, as defined in Section 5.1. The thermal mass of the MCO shell may be included.

\subsubsection{MCO Dimensions and Gross Weight}

The dimensions of the MCO and its gross weight (including the fuel elements) to be assumed for the thermal calculations is defined in Table 6 .

\subsubsection{Maximum MCO Temperature}

The maximum temperature allowed for the MCO shell under normal transport conditions shal1 be $75^{\circ} \mathrm{C}\left(167{ }^{\circ} \mathrm{F}\right)$.

Under the accident conditions, the temperature of the MCO shell may exceed the temperature 1 imit for the normal conditions of transport for a time period not to exceed 180 minutes following the fire and shall not exceed a maximum of $122{ }^{\circ} \mathrm{C}\left(252^{\circ} \mathrm{F}\right)$. 
Table 6. Preliminary Dimensions and Weight of the MCO.

\begin{tabular}{|l|l|}
\hline \multicolumn{1}{|c|}{ Payload configuration } & \multicolumn{1}{|c|}{ Figure 1 } \\
\hline MCO length & $160 \mathrm{in}$. \\
\hline MCO diameter & $24 \mathrm{in}$. \\
\hline MCO wall & $0.5 \mathrm{in}$. \\
\hline MCO volume & $272 \mathrm{gal}$ \\
\hline MCO empty & $1,954 \mathrm{lb}$ \\
\hline Basket weight & $750 \mathrm{lb}$ \\
\hline MCO top 10-in. shield & $1,226 \mathrm{lb}$ \\
\hline Zr cladding & $980 \mathrm{lb}$ \\
\hline Fuel and cladding & $15,050 \mathrm{lb} / \mathrm{MCO}$ \\
\hline Total MCO weight & $19,000 \mathrm{lb}$ \\
\hline
\end{tabular}

MCO = Multiple Canister Overpack.

\subsection{TRANSPORTATION CLASSIFICATION}

For transportation purposes, the irradiated fuel payload of the packaging is considered Type B, Highway Route Controlled Quantity (HRCQ), fissile, spent fue1. The transport will be administratively controlled based on the potential dose consequences associated with the payload.

\subsection{FISSILE CLASSIFICATION}

The payload shall be classified as fissile material for transportation. The maximum fissile content per cask is $60,036 \mathrm{~g}$ for the worst-case Mark IV fuel rerack scenario. A criticality analysis will be performed to determine the fissile classification of the shipment and will be evaluated in the SARP.

\subsection{CONTENT RESTRICTIONS}

The MCO cask payload shall be 1 imited to nuclear fuel elements cleaned and placed in baskets that have been loaded into an MCO. 
WHC-SD-TP-PDC-030 Rev. 2

\subsection{FACILITY OPERATIONS}

\subsection{ORIGINATING SITE--K BASINS}

The loading of the MCO and packaging shall take place either underwater or above the water in either of the loadout pits of the $K$ East and $K$ West Basins (Figure 3 ). This facility is limited in space and lifting capabilities. The MCO may be placed into the MCO cask prior to the loading of the reracked fuel baskets into the MCO. The fuel baskets shall be prepared, as necessary, for the conditioning process prior to being loaded into the MCO. Further conditioning of the fuel, such as vacuum drying, may take place with the MCO in the cask. The package shall be mounted on the transfer vehicle before leaving the basin. The exterior package contamination limits must be met, as shown in Table 7, prior to transportation. Prior to reuse of the cask, the cask internal cavity shall be decontaminated to less than 100 times the removable contamination 1 imits set forth in Table 7 . Figure 4 provides a sketch of the $K$ East and $K$ West loading areas, which are identical. Limited modifications of the loading area may be necessary to improve the fuel-loading and package-handling capabilities of the facility.

Table 7. External Cask Contamination Limits.

\begin{tabular}{|c|c|c|}
\hline \multirow{2}{*}{ Contaminant } & \multicolumn{2}{|c|}{ Maximum permissible limits } \\
\hline & $\begin{array}{l}\text { Removable, } \\
\mathrm{dpm} / 100 \mathrm{~cm}^{2}\end{array}$ & $\begin{array}{l}\text { Fixed + removable } \\
\quad \mathrm{dpm} / 100 \mathrm{~cm}^{2}\end{array}$ \\
\hline U-natural, U-235, U-238 and associate decay products & 1,000 alpha & 5,000 alpha \\
\hline $\begin{array}{l}\text { Transuranics, Ra-226, Ra-228, Th-230, Th-228, Pa-231, } \\
\text { Ac-227, I-129 }\end{array}$ & 20 & 500 \\
\hline $\begin{array}{l}\text { Th-natural, Th-232, } \mathrm{S} r-90, \mathrm{Ra}-223, \mathrm{Ra}-224, \mathrm{U}-232 \text {, } \\
\mathrm{I}-125, \mathrm{I}-126, \mathrm{I}-131, \mathrm{I}-133\end{array}$ & 200 & 1,000 \\
\hline $\begin{array}{l}\text { Beta-gamma emitters except } \mathrm{Sr}-90 \text { and other noted above. } \\
\text { Includes mixed fission products containing } \mathrm{Sr}-90 \text {. }\end{array}$ & 1,000 beta-gamma & 5,000 beta-gamma \\
\hline $\begin{array}{l}\text { Tritium organic compounds, surfaces contaminated by HT, } \\
\text { HTO, and metal tritide aerosols }\end{array}$ & 10,000 & 10,000 \\
\hline
\end{tabular}

Source: HSRCM-1, 1994, Manford Site Radiological Control Manual. Table 2-2, Summary of Contamination Values.

\subsection{DESTINATION SITE--CSB}

Off-loading of the package shall take place at the CSB (Figure 5) in the 200 East Area. This activity shall involve the removal of the MCO from the package. The MCO will be staged at the CSB, possibly undergo further conditioning in a separate conditioning facility, and then be returned for storage in the CSB. The packaging sha11 al so be decontaminated to Table 7 limits and inspected, as needed, before transport back to the $K$ Basins. 


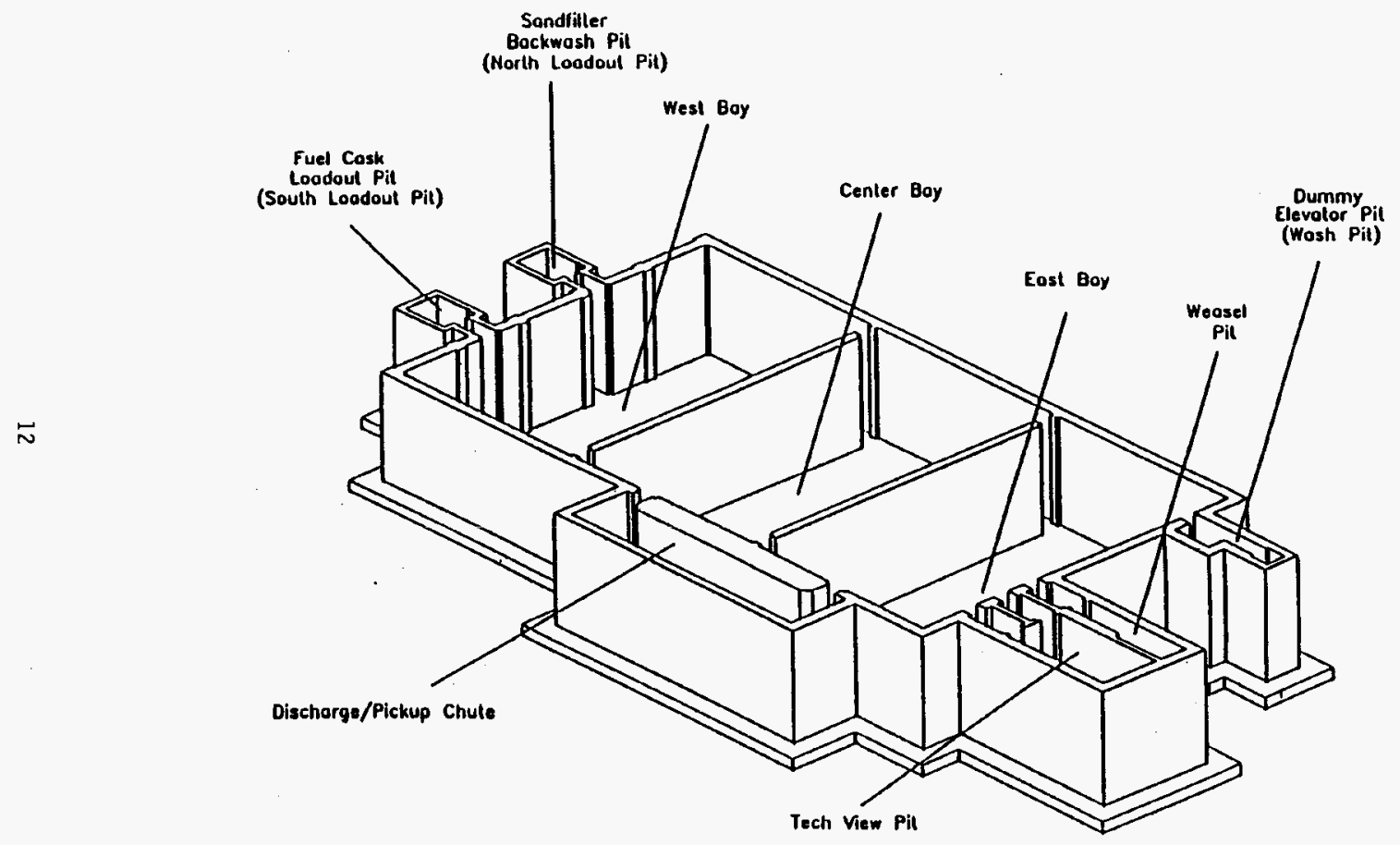

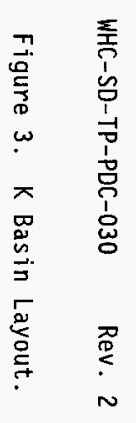


WHC-SD-TP-PDC-030 Rev. 2

Figure 4. K Basin East and West Loadout Area.

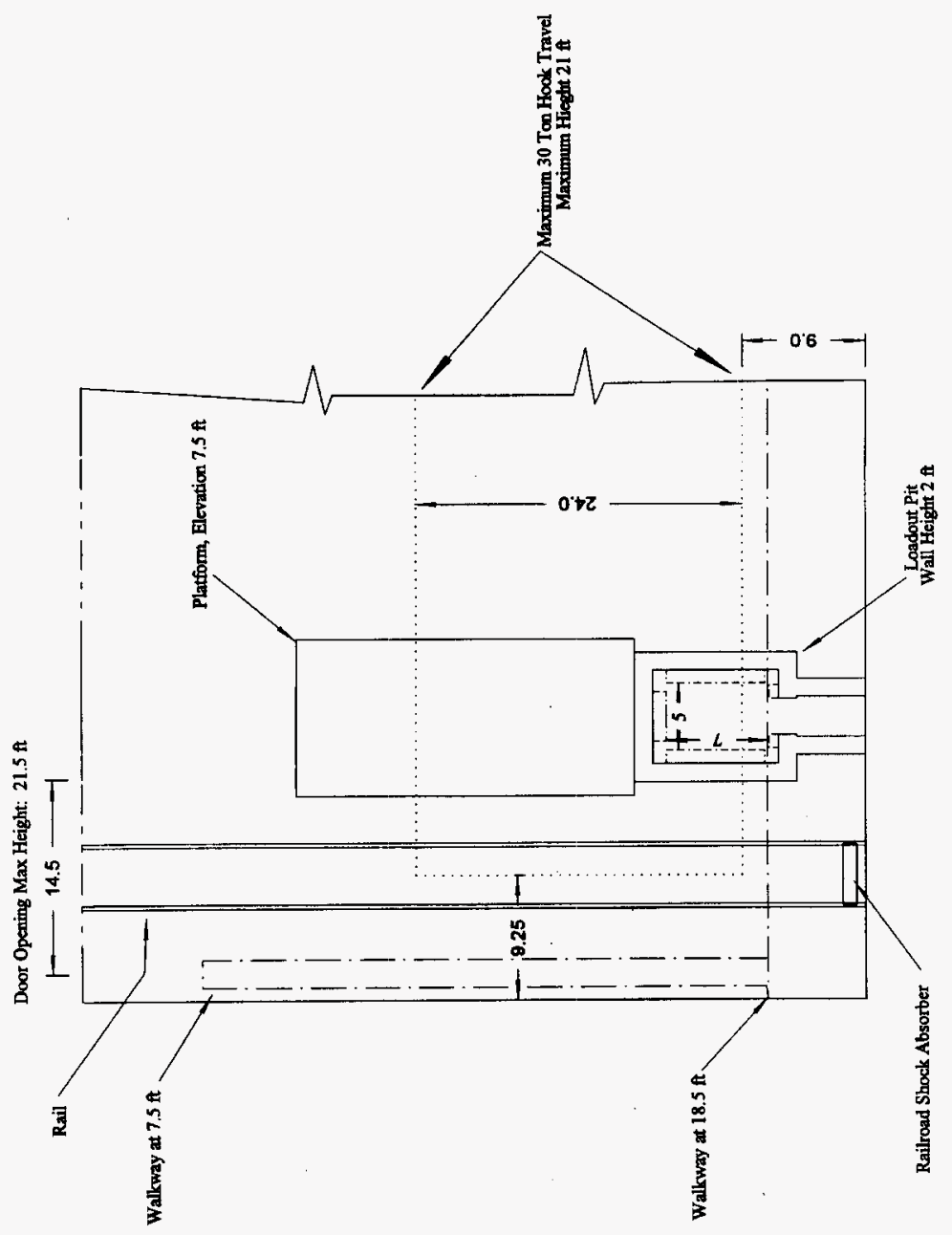


WHC-SD-TP-PDC-030 Rev. 2

Figure 5. Canister Storage Building Loadout Area.

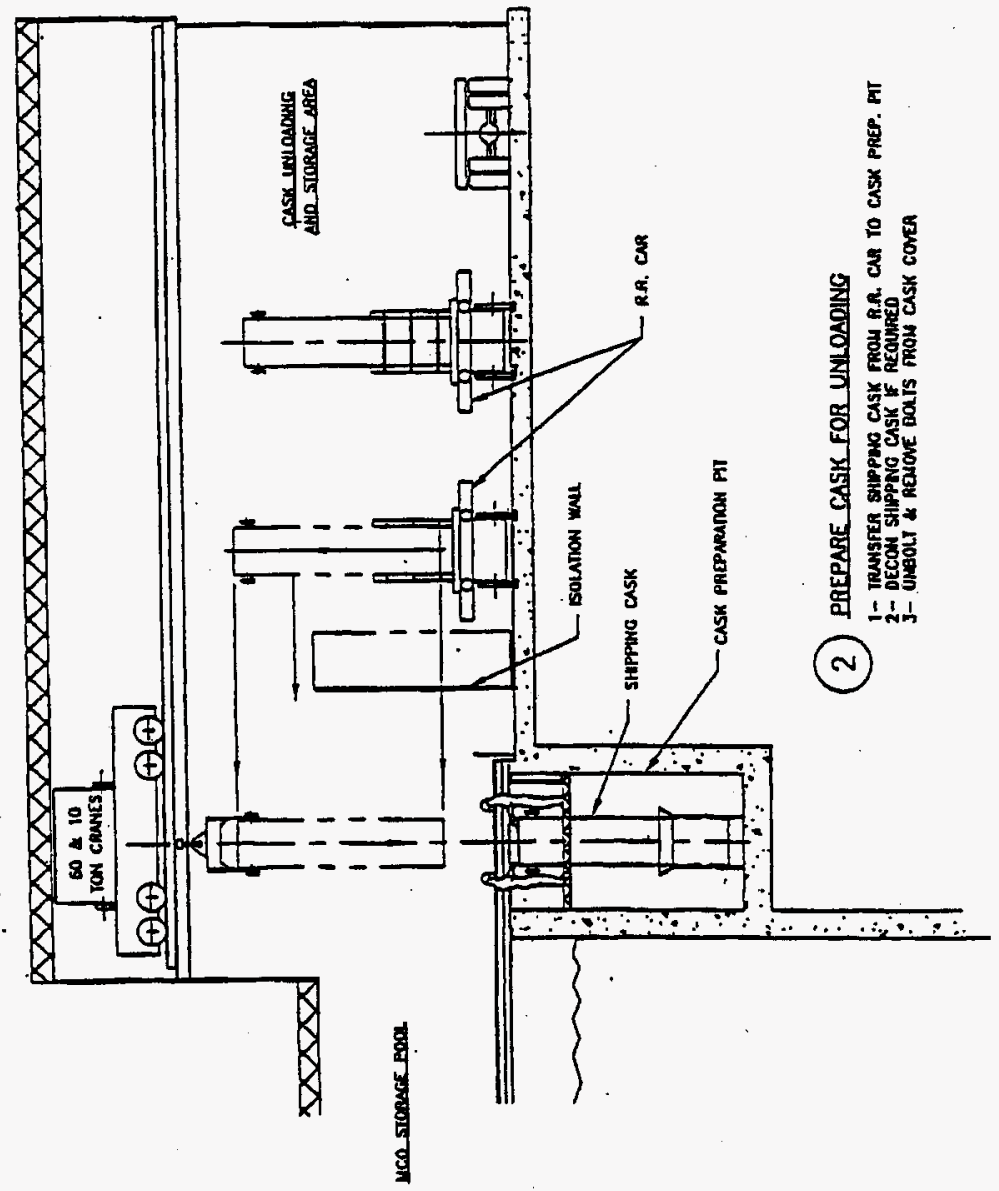


WHC-SD-TP-PDC-030 Rev. 2

\subsection{PACKAGING/TRANSPORT SYSTEM DESIGN}

\subsection{GENERAL}

The packaging shall be approved for use within the boundaries of the Hanford site. It will be authorized to transfer Type B, HRCQ of fissile radioactive material in the form of irradiated fuel assemblies. A SARP shall be written to demonstrate the safety of the transfer through a combination of cask performance and administrative controls as per the Report on Equivalent Safety for Onsite Packaging and Transportation (WHC 1994). The SARP will include the evaluation of the packaging system to provide containment, shielding, and subcriticality for the payload during normal (Section 5.1.1) and accident conditions (Section 5.1.2). The packaging and transportation shall be performed in accordance with WHC-CM-2-14, Hazardous Material Shipping and Packaging Manual. Approval of the SARP provides authorization for onsite transport.

\subsection{PACKAGING DESIGN CRITERIA}

The packaging shall be designed as a reusable system capable of being loaded and unloaded both in air and underwater. The MCO cask shall be capable of carrying at least one MCO. The design of the MCO cask shall be such that the MCO is capable of being loaded with irradiated fuel elements in baskets before or after the MCO is placed in the inner cavity of the cask. The MCO cask design shall be such that the MCO may be welded after being loaded into the packaging cavity. The cask may be top and/or bottom loaded. The cask design shall allow draining of water from the cask cavity prior to transport.

Package performance requirements during normal and accident transport conditions will be verified through analysis, or a combination of analytical and test methods, for a bounding case scenario. The results shall demonstrate that any material release falls within the dose consequence limits of Section 5.1.2.1.

\subsubsection{Packaging Materials}

The structural containment boundary materials for the packaging shall comply with material requirements ident ified in NUREG/CR-3854, Fabrication criteria for Shipping Containers (Fischer and Lai 1985). The materials of construction shall meet the fracture toughness requirements of Regulatory Guide 7.11 (NRC 1991a) or Regulatory Guide 7.12 (NRC 1991b), as applicable. There shall be an equivalent wall thickness (all wall materials) of at least $7.62-\mathrm{cm}(3-i n$.$) steel, based on puncture resistance thresholds.$

All materials, including lead (if required for shielding purposes), shall be American Society of Mechanical Engineers (ASME) or American Society for Testing and Materials (ASTM)-certified materials or other recognized national or industrial standards for materials other than steel or stainless steel. The materials shall be compatible with or provide adequate resistance to the 


$$
\text { WHC-SD-TP-PDC-030 Rev. } 2
$$

corrosive effects of materials (liquids, vapors, gases, and solids) that they will be in contact with throughout their life cycle (20 years). The materials shall also be selected to minimize chemical-galvanic reactions between payload components and the packaging.

\subsubsection{Fabrication Methods}

Fabrication criteria for a Category I packaging, as delineated in NUREG/CR-3854 (Fischer and Lai 1985), shall be followed. Fabrication of the packaging shall be performed in accordance with ASME (1992) Section III, as required by NUREG/CR-3854.

Welding criteria for a Category I packaging, as delineated in NUREG/CR-3019 (Monroe et al. 1984), shall be followed. All welds and weld joints sha11 be examined per ASME (1992) Section III. Welds shall be inspected in accordance with the examination methods of ASME (1992) Section V, except as modified by the requirements of Section III. Welders shall be qualified per ASME (1992) Section IX.

A11 welds shall be sufficiently smooth to enable easy decontamination. The design shall consider avoiding potential contamination traps to the greatest extent practicable. All containment welds shall be inspected per ASME Section III, Subsection NB, requirements.

Decontamination of all external surfaces will be required to meet Table 7 limits. Surface areas that may contact radioactive materials shall be designed for ease of decontamination.

All of the above requirements apply to the fabrication of the MCO and the MCO Cask. However, an exception from the above criteria may be taken for the MCO. Examination of the MCO closure weld may be limited to liquid penetrant or magnetic particle examination of the root and final passes if the MCO closure weld is designed as a partial penetration weld that does not take credit for the thickness of the root pass.

\subsubsection{Packaging Dimensions}

The dimensions for the internal cavity of the packaging must be sufficient to accommodate the MCO. The MCO concept maximum dimensions are $406 \mathrm{~cm}$ (160 in.) long by $61 \mathrm{~cm}(24 \mathrm{in}$.) in diameter.

The maximum dimensions for the packaging exterior shall be based on the handling limits of the $\mathrm{K}$ Basins and CSB, shown in Figures 4 and 5 .

\subsubsection{Maximum Gross Weight}

The weight of a package fully loaded with reracked fuel, water, etc., shall not exceed $27,210 \mathrm{~kg}$ ( 30 tons). The package shall be configured to be handled with the $K$ Basin crane. The maximum lifting capacity of this crane is $27,210 \mathrm{~kg}$ (30 tons). 
WHC-SD-TP-PDC-030 Rev. 2

\subsubsection{Lifting and Tiedown Attachments}

The lifting attachments for the packaging shall be capable of lifting three times the total suspended weight without generating a combined stress or maximum tensile stress at any point in the load path in excess of the corresponding minimum yield strength of their materials of construction. The lifting attachments shall be compatible with the cranes in the $K$ Basins loadout area, CSB cranes, and portable cranes to permit field lifting of the packaging.

If the tiedown attachments are a structural part of the packaging, they shall be designed to withstand a force of ten times the package weight in the forward and aft directions; five times the gross package weight in the lateral directions; and two times the package weight in the vertical directions without yielding.

\subsubsection{Venting}

The packaging design shall incorporate vents for sampling the cask cavity. Any vents that are incorporated in the design must be capable of being closed and leaktight during normal transport conditions. During and subsequent to accident conditions, the release of materials from the package, including the venting system, shall not exceed the limits set in

Section 5.1.2.

\subsubsection{Loading}

The packaging shall be capable of being loaded underwater or in air. The packaging shall be capable of being top-loaded with an empty or full MCO or bottom-loaded with a full MCO.

\subsubsection{Draining}

The packaging shall be outfitted with a drain port and high port vent that will permit removal of 1 iquids from the cask cavity with or without a fully loaded MCO loaded into the cask. The drain port and high port vent shall be capable of being opened and closed using remote handing equipment.

\subsubsection{Water Circulation}

The packaging shall be equipped with features that permit circulation of a minimum of $76 \mathrm{~L} / \mathrm{min}(20 \mathrm{gpm}), 50^{\circ} \mathrm{C}\left(122^{\circ} \mathrm{F}\right)$, water through the package/MCO annulus for the cold vacuum drying process. This feature shall provide a uniform water temperature flow around the MCO. The system shall provide double shut-off quick release interfaces to the inlet and outlet ports on the cask. The design shall include features that will retain the $M C O$ in the packaging for all normal and off-normal pressures in the annulus. 


$$
\text { WHC-SD-TP-PDC-030 Rev. } 2
$$

\subsubsection{Closure}

Each packaging closure shall be securely closed with a positive fastening device that cannot be opened unintentionally. The cask closure shall be simple to install, leak testable, and reliable. The cask payload cavity shall be provided with the capability to be filled and purged with inert gas.

\subsubsection{Containment}

The MCO cask shall provide the transportation containment barrier for the payload, as described below. The MCO will provide one additional level of containment. The packaging shall be designed so that during normal transfer conditions (Section 5.1.1), the package remains leaktight, as demonstrated through testing and/or analysis. Linear-elastic analysis may be performed to demonstrate maintenance of the leakage rate after the normal transfer conditions. ASME (1992) Section III, Service Level A stress allowables shall be used for analytical acceptance.

The cask system shall also be designed such that, during accident conditions (Section 5.1.2) the package maintains a single confinement barrier for the MCO, as demonstrated by analysis and/or testing. Elastic-plastic analysis may be performed to demonstrate maintenance of confinement after the accident conditions. ASME (1992) Section III, Service Level D stress allowables shall be used for analytical acceptance. Energy absorbed by the package during the drop is accounted for based on elastic-plastic analysis. During the fire scenario, the MCO cask seals may deteriorate such that loss of the cask containment seal occurs.

\subsubsection{Shielding}

As low as reasonably achievable (ALARA) principles will be the limiting factor for the design dose rate of the package. The packaging and closures ( 1 id, vent ports, leak test ports, etc.) shall be designed to ensure that they provide adequate shielding.

\subsubsection{Maintenance}

The packaging and ancillary components shall be designed to minimize maintenance or testing requirements. Features requiring maintenance shall be designed in accordance with ALARA principles using the guidance found in HSRCM-1, Hanford Site Radiological Control Manual.

\subsubsection{Life Cycie}

The packaging shall be capable of being reused a minimum of 1,000 times. The MCO is used only one time for transportation and is the long-term storage container. Additionally, the packaging shall have a minimum transport service 1ife of 20 years. Design features of the packaging shall minimize maintenance, refurbishing, and decontamination procedures required for 
WHC-SD-TP-PDC-030 Rev. 2

packaging reuse. Features requiring refurbishment prior to reuse shall be designed in accordance with ALARA principles, as per HSRCM-1.

The SARP will provide the necessary requirements, such as inspections and part replacements, to allow for the safe and effective reuse of the cask.

\subsection{TRANSPORT SYSTEM}

\subsubsection{General}

The transport operation involves loading the irradiated fuel into the MCO and packaging at the $100 \mathrm{~K}$ East and West Basins, and securing the package to a transport vehicle before shipment of the fue1. Figure 4 provides a sketch of the $100 \mathrm{~K}$ East and West 10 ading areas. Limited modifications to the $\mathrm{K}$ East and $K$ West loading areas, which are identical, may be possible to facilitate loading and handling of the package.

Transport of the package is from the $100 \mathrm{~K}$ Area to the CSB in the 200 East Area for further conditioning and storage. The package will be transported by truck. The total loaded transport distance will be approximately $16.1 \mathrm{~km}$ (10 $\mathrm{mi})$.

The transportation campaign shall use existing onsite transport vehicles, if possible. Modifications required for adaptation of the transport vehicle shall be minimized.

\subsubsection{Truck Transport System}

The package transportation system may use a specially equipped trailer capable of transporting a minimum of one package per shipment. This trailer shall be built to all applicable U.S. Department of Transportation standards and will be capable of being pulled by tractors presently available for use on the Hanford Site. The trailer shall be a National Highway Traffic Safety Administration-registered trajler and meet all requirements of the enhanced Commercial Vehicle Safety Alliance inspection. Additional standards for the trailer to ensure compatibility with the $K$ Basins and CSB facilities are as follows.

- The maximum gross weight per axle for a fully loaded tractor/trailer combination shall not exceed $9,100 \mathrm{~kg}(20,000$ 1bs).

- The maximum width of the tractor/trailer combination shall not exceed $3.96 \mathrm{~m}(13 \mathrm{ft})$.

- Dimensions with the cask system attached in a horizontal or vertical configuration shall allow access to the interfacing facilities.

- The height of the trailer bed shall be limited so that the combined height of the cask, with tiedowns and impact limiters, if used, shal1 not exceed $6.15 \mathrm{~m}$ (20 ft $2 \mathrm{in}$.) when mounted to the trailer. 
WHC-SD-TP-PDC-030 Rev. 2

- The trailer shall be equipped with tiedown points sufficient to secure the cask in accordance with the requirements set forth in Section 4.4 .

\subsubsection{Additional Requirements}

To prevent the trailer from tipping over during normal transport, the trailer shall be designed in accordance with ANSI Standard N14.30 (ANSI 1992), Section 5.1.2.1. This standard requires the center of gravity of the trailer and its load to be within $5.08 \mathrm{~cm}(2.0 \mathrm{in}$.) of the transverse center of the trailer and requires the height of the center of gravity to be less than $120 \%$ of the trailer track (center-to-center width of the trailer tire group).

\subsection{TIEDOWN SYSTEM}

An engineered tiedown system shall be used to secure the packaging system to the transport vehicle(s). The tiedown system shall meet the requirements and be designed per the International Atomic Energy Agency Safety Series 37 (IAEA 1990). The tiedown attachments for those requirements shall be capable of resisting the forces for road or rail, as described in Table 8.

Table 8. Load Factors for Tiedown Systems.

\begin{tabular}{|c|c|c|c|}
\hline Mode & Longitudinal & Lateral & Vertical \\
\hline Road & $+2 g$ & $+/-1 g$ & $3 g$ down, $2 g$ up \\
\hline
\end{tabular}

Consideration shal1 be given to tiedown methods (such as remote operations or permanent systems integral to the packaging and transport vehicle) to maximize the distance and/or minimize the time spent near the payload.

\subsection{GENERAL REQUIREMENTS}

\subsection{TRANSPORTATION SYSTEM}

\subsubsection{Normal Conditions of Transport}

For conditions normally incident to transport, the SARP shall evaluate the packaging design for its ability to maintain containment, shielding, and nuclear criticality control when subjected to the following conditions.

- Environmental Conditions. The design temperature limits for the individual components, parts, and materials of the package shatl be 
determined by analyses and/or testing. The analyses and/or tests shall be based upon the conditions listed below. The operational temperatures sha11 be shown to not exceed the design limits. The ambient temperatures at the Hanford Site for the peak summer month are tabulated in Table 9.

Table 9. Hanford Air Temperature.

\begin{tabular}{|c|c|c|c|}
\hline Time & $\begin{array}{c}\text { Temperature } \\
\left({ }^{\circ} \mathrm{F}\right)\end{array}$ & Time & $\begin{array}{c}\text { Temperature } \\
\left({ }^{\circ} \mathrm{F}\right)\end{array}$ \\
\hline 12 a.m. & 82 & 2 p.m. & 111 \\
\hline 2 a.m. & 78 & 4 p.m. & 115 \\
\hline 4 a.m. & 75 & 6 p.m. & 113 \\
\hline 6 a.m. & 74 & 8 p.m. & 100 \\
\hline 8 a.m. & 85 & 10 p.m. & 89 \\
\hline 10 a.m. & 97 & 12 a.m. & 82 \\
\hline 12 p.m. & 103 & \multicolumn{2}{|c}{} \\
\cline { 1 - 3 } & & &
\end{tabular}

- Maximum heat generation rate of worst-case source from Section 2.2 plus maximum solar heat load (see Table 10) plus maximum air temperature of $46^{\circ} \mathrm{C}\left(115^{\circ} \mathrm{F}\right)$

- Minimum air temperature of $-33^{\circ} \mathrm{C}\left(-27^{\circ} \mathrm{F}\right)$ plus maximum heat generation rate from worst-case source in Section 2.2

- Minimum air temperature of $-33^{\circ} \mathrm{C}\left(-27{ }^{\circ} \mathrm{F}\right)$ and zero heat generation rate.

Table 10. Maximum Solar Radiation Received from the Sun (BTU/h-ft $\mathrm{f}^{2}$.

\begin{tabular}{|c|c|c|c|c|c|c|c|c|c|}
\hline \multirow{2}{*}{ Time } & \multicolumn{8}{|c|}{ Vertical surfaces facing } & \multirow{2}{*}{$\begin{array}{l}\text { Hor izontal } \\
\text { surface } \\
\text { facing up }\end{array}$} \\
\hline & $\mathrm{N}$ & ME & $\mathrm{E}$ & SE & 5 & SW & $\omega$ & NW & \\
\hline 4 a.m. & 0 & 0 & 0 & 0 & 0 & 0 & 0 & 0 & 0 \\
\hline 6 a.m. & 57 & 192 & 211 & 105 & 17 & 17 & 17 & 17 & 64 \\
\hline 8 a.m. & 35 & 173 & 268 & 208 & 42 & 32 & 32 & 32 & 127 \\
\hline $10 \mathrm{a} . \mathrm{m}$. & 42 & 56 & 177 & 213 & 126 & 45 & 42 & 42 & 281 \\
\hline 12 noon & 45 & 45 & 49 & 120 & 167 & 120 & 49 & 45 & 314 \\
\hline 2 p.m. & 42 & 42 & 42 & 45 & 126 & 213 & 177 & 56 & 281 \\
\hline 4 p.m. & 35 & 32 & 32 & 32 & 52 & 208 & 268 & 173 & 127 \\
\hline 6 p.m. & 57 & 17 & 17 & 17 & 17 & 105 & 211 & 192 & 64 \\
\hline 8 p.m. & 0 & 0 & 0 & 0 & 0 & 0 & 0 & 0 & 0 \\
\hline
\end{tabular}


WHC-SD-TP-PDC-030 Rev. 2

Maximum normal operating outside surface temperature of the cask shall be less than $82{ }^{\circ} \mathrm{C}\left(180^{\circ} \mathrm{F}\right)$ in maximum air temperature and in the shade.

- Reduced External Pressure. An external pressure of $24.5 \mathrm{kPa}$ (3.5 psi) absolute.

- Increased External Pressure. An external pressure of $140 \mathrm{kPa}$ (20 psi) absolute.

- Internal Pressure. An internal working pressure of 1,033 kPa (150 psig) unless otherwise specified.

- Vibration. Vibration normally incident to transport. The package shall be evaluated per ANSI N14.23 to demonstrate containment when exposed to normal vibration due to the transportation from the $100 \mathrm{~K}$ West and East Basins to the CSB in the 200 East Area by the selected transport vehicle. Tiedowns and holddown bolts shall also be evaluated for this scenario.

- Free Drop. The package shall be evaluated to demonstrate containment subsequent to a $0.3-\mathrm{m}(1-\mathrm{ft})$ free drop onto an 8 -in.thick concrete surface with a concrete strength of 4,000 psi, a Soil Modulus of Elasticity of 28,000 psi, and Grade 60, No. 7 rebar spaced 12. in. apart with 2-in. cover, each way, each face. The package shall impact in an orientation expected to cause maximum damage. Secondary impact of the package (slapdown) does not have to be examined for this drop. During the free drop, the MCO shall not be exposed to greater than $100 \mathrm{~g}^{\prime} \mathrm{s}$ and shall maintain containment.

- Water Spray. The package shall be evaluated to demonstrate containment through a water spray that simulates exposure to rainfall of approximately $5 \mathrm{~cm}$ (2 in.) per hour for at least one hour.

- Penetration. Impact of the hemispherical end of a vertical steel cylinder of 3.2-cm (1.25-in.) diameter and 6-kg (13-1b) mass, dropped from a height of $1 \mathrm{~m}$ (40 in.) onto the exposed surface of the package that is expected to be most vulnerable to puncture. The long axis of the cylinder must be perpendicular to the package surface.

5.1.1.1 Containment. The cask shall be designed, constructed, and prepared for shipment so that when subjected to normal conditions, the containment boundary shall remain leaktight in accordance with the ANSI 14.5 definition of "leaktight." If the package design incorporates a venting feature, the leakage rate evaluation shall be made with the vent(s) sealed.

For conditions normally incident to transport, the packaging sha11 be evaluated by analysis to meet the containment criteria listed above.

5.1.1.2 Shielding. For exclusive use normal conditions of transport, as described in Section 5.1.1, the maximum surface dose on the accessible surface of the package shall not exceed $200 \mathrm{mR} / \mathrm{h}$. The dose rate $2 \mathrm{~m}(6.5 \mathrm{ft})$ from the 
WHC-SD-TP-PDC-030 Rev: 2

surface shall be 1 imited to $10 \mathrm{mrem} / \mathrm{h}$. The dose in any normally occupied space in the transfer vehicle shall be 1 imited to $2 \mathrm{mrem} / \mathrm{h}$ or less.

5.1.1.3 Criticality. The package design shall also ensure that twice the number of packages will meet the following criteria.

The contents shall remain subcritical ( $k_{\text {eff }}$ less than 0.95 , where 0.95 is the mean value plus two times the one standard deviation value [two standard deviations] with bias applied) for the packages during normal conditions of transport, as described in

Section 5.1.1, also assuming the following.

- The most reactive credible configuration is consistent with the chemical and physical form of the allowed packaged material.

- There is clustering of packages and close reflection of the package array by water on all sides.

\subsubsection{Accident Conditions}

The report on equivalent safety (WHC 1994) provides a description of how a highly controlled transportation environment, such as that available on the Hanford Reservation, can contribute to the safety of a packaging system. H\&R (1995) uses accident data from the Hanford Site and other controlled transportation environments to establish the worst-case credible accidents (frequency greater than $10^{-6}$ accidents/year) for the packaging system.

Based on the preliminary risk evaluation (Green 1996), the following worst-case accidents meet the equivalent safety-based design criteria. For purposes of onsite package evaluation, these events are assumed to occur nonsequentially. For design evaluation, these accidents shall be evaluated at an ambient temperature between $-32^{\circ} \mathrm{C}\left(-27^{\circ} \mathrm{F}\right)$ and $47^{\circ} \mathrm{C}\left(115^{\circ} \mathrm{F}\right)$, whichever was more severe for the individual incident. Additionally, the packaging system will be evaluated carrying the worst-case payload, as described in Section 2.0.

- Puncture. The worst-case credible puncture incident is equivalent to a free drop of the packaging through a distance of $1 \mathrm{~m}$ (40 in.) in a position expected to cause the maximum damage, onto the upper end of a solid, vertical, cylindrical, mild-steel bar mounted on an essentially unyielding, horizontal surface. The bar must be $15 \mathrm{~cm}$ ( 6 in.) in diameter, with the top horizontal and its edge rounded to a radius of not more than $6 \mathrm{~mm}(0.25 \mathrm{in}$.) and of a length to cause maximum damage to the package, but not less than $20 \mathrm{~cm}$ ( 8 in.) long. Acceptance to this requirement is that there is no loss of shielding to the extent shown below in Section 5.1.2.2.

- Impact. The worst-case credible impact for the packaging system may be simulated by a free drop of $30 \mathrm{ft}$ onto an 8-in.-thick concrete surface with a concrete strength of $4,000 \mathrm{psi}$, a Soil Modulus of Elasticity of 28,000 psi, and Grade 60, No. 7 rebar spaced 12 in. apart with 2 -in. cover, each way, each face. The package shall 
impact in an orientation expected to cause maximum damage. The MCO sha11 not be exposed to greater than $100 \mathrm{~g}$ 's during this drop scenario.

- Therma1. Exposure of the packaging system for not less than 30 minutes to a $800^{\circ} \mathrm{C}\left(1,475^{\circ} \mathrm{F}\right)$ engulfing fire that has an emissivity coefficient of 0.9 . The surface absorptivity of the package shall be the greater of the anticipated absorptivity or 0.8 . The package can be assumed to be cooled after the fire. Any active cooling system for the packaging shall be assumed to be inoperative during the fire.

Active cooling of the package following the 30-minute fire can be assumed. If assumed, the active cooling shall consist of quenching the outer package surfaces using water spray from a fire hose rated at $125 \mathrm{gal} / \mathrm{min}$. Flow at this maximum flow rate shall be assumed to occur for a minimum of 45 minutes. If needed, additional quenching water flow can be assumed for an additional period of 100 minutes at a maximum flow rate of $50 \mathrm{gal} / \mathrm{min}$. Assume a water temperature of $29^{\circ} \mathrm{C}\left(85^{\circ} \mathrm{F}\right)$ for this procedure.

5.1.2.1 Containment. During and subsequent to all credible or probable accident events, as described in Section 5.1.2, the packaging system sha11 maintain confinement of the MCO (not allow the MCO to be released from the cask) and not allow a significant release of radioactive material to the environment (release the fuel elements from the cask and MCO). A radiological risk evaluation will support the credible accident scenarios.

5.1.2.2 Shielding. Subsequent to all credible or probable accident events, as described in Section 5.1.2, the dose $1 \mathrm{~m}(3.3 \mathrm{ft})$ from the surface of the packaging system shall not exceed $1 \mathrm{rem} / \mathrm{h}$. Due to the fire event, there shall be no net loss of lead shielding, if lead is used. The lead may melt, but cannot be lost.

5.1.2.3 Criticality. Subsequent to all credible or probable accident events, as described in Section 5.1.2, the packaging system shall be evaluated for one package to meet the following criteria.

The contents shall remain subcritical ( $k_{\text {eff }}$ less than 0.95 , as defined in Section 5.1.1.3) for the packaging system during and subsequent to an accident condition, also assuming the following.

- The fissile material is in the most reactive credible configuration consistent with the chemical form and damaged condition of the package and payload.

- There is optimum interspersed aqueous moderation.

- There is clustering of packages and close reflection of the package array by water on all sides.

5.1.2.4 Risk Evaluation. The preliminary risk evaluation was performed to establish the equivalent safety-based design criteria. This assessment was 
WHC-SD-TP-PDC-030 Rev. 2

used to develop the design criteria stated in 5.1.2. A radiological risk evaluation will be developed for the SARP and will evaluate credible accident scenarios to meet the onsite transportation safety criteria.

\subsection{ALARA}

The design features of the packages shall be consistent with the requirements of WHC Occupational ALARA Program (WHC 1995), for the Hanford Site. Exposure of personnel to radiological and other hazardous materials associated with the loading, closure, tiedown, transfer, and off-loading of the package shall be minimized. Cost benefit analyses should be performed, as needed, to determine the best balance between exposure and economical design.

The contamination 1 imits, as directed by HSRCM-1, Article 423.2 (see Table 7), will be met prior to transport of the packaging.

\section{$5.3 Q A$}

The QA program requirements for activities such as design, procurement, fabrication, inspection, testing, component handling, and documentation of the fuel casks and their components shall be equivalent to 10 CFR 71, Subpart H, and WHC-CM-4-2, Quality Assurance Manual.

To establish a QA plan for the packagings, a graded approach shall be used to define the safety class of both the system and individual components of the packaging system. The application of the safety class system is fully documented in WHC-CM-4-46, Nonreactor Facility Safety Analysis Manua7. The criteria for transportation safety class evaluations are documented in WHC-SD-TP-RPT-001 (WHC 1994). QA requirements shall be developed for the procurement, fabrication, and inspection of the package based on the assigned transportation safety class of the package.

\subsubsection{System Safety Class}

The transportation safety class of the packages with a worst-case payload was determined by a dose consequence study, documented in Appendix $A$. This study assumed a total failure of the canister packaging system and the release of all of its contents to the environment at the worst possible location on the transportation route. For the shipment of the irradiated fuel, the worstcase release location is within the $100 \mathrm{~K}$ Area, just outside the Basins.

The transportation safety class dose consequence study (Appendix A), performed for 270 elements in the rerack basket scenario, indicates that the maximum inhalation dose to an onsite receptor is 240,000 rem effective dose equivalent (EDE), and the maximum inhalation dose to an offsite receptor is 120 rem EDE. Therefore, for 270 reracked elements, the packaging constitutes a Safety Class 1 system per WHC-SD-TP-RPT-001 (WHC 1994) and WHC-CM-4-46.

For transportation packages with HRCQ material and a Safety CTass 1, ASME (1992) Section III shall be used as guidelines for the design. 
WHC-SD-TP-PDC-030 Rev. 2

\subsection{DESIGN FORMAT}

Development of the design drawings, design changes, and other design documentation, if required, shall be in accordance with WHC-CM-6-1, Standard Engineering Practices.

\subsection{ENVIRONMENTAL COMPLIANCE}

Actions and conditions for the protection of the environment during transport of the packaging shall comply with the requirements of WHC-CM-7-5, Environmental Compliance.

\subsection{MAINTENANCE}

Maintenance, as required and specified in the SARP, shall be performed on the packaging to ensure packaging integrity is maintained. Ease and minimization of maintenance shall be considered in the design of the packaging. Vendor-supplied spare parts and maintenance data, if applicable, shall be provided for equipment specified in the design. Special tools required to operate the packaging system and/or replace/repair components shall also be provided as part of the project.

\subsection{SARP}

A SARP will be prepared based upon the above design criteria that will provide the safety analysis necessary to demonstrate that the packaging meets or exceeds all Hanford Site packaging safety acceptance criteria. Operational (loading and off-loading), maintenance, acceptance, and QA criteria will be included in the SARP, ensuring that operation, transport, and storage of the package meets the requirements of this PDC. The onsite SARP table of contents is found in Appendix $B$.

\subsection{REFERENCES}

10 CFR 71, 1994, "Packaging and Transportation of Radioactive Material, "Code of Federal Regulations, as amended.

49 CFR 173, 1994, "Shippers--General Requirements for Shipments and Packagings," Code of Federal Regulations, as amended.

ASME, 1992, ASME Boiler \& Pressure Vessel Code, American Society of Mechanical Engineers, New York, New York.

Fischer, L. E., and W. Lai, 1985, Fabrication Criteria for Shipping Containers, NUREG/CR-3854 (under Lawrence Livermore National Laboratory contract to the U.S. Nuclear Regulatory Commission), U.S. Nuclear Regulatory Commission, Washington, D.C. 
WHC-SD-TP-PDC-030 Rev. 2

Green, J. R., 1996, Radiological Risk Evaluation for Risk-Based Design Criteria of the Multiple Container Overpack Packaging, WHC-SD-TP-RPT-022, Rev. 1, Westinghouse Hanford Company, Richland, Washington.

H\&R, 1995, Recommended Onsite Transportation Risk Management Methodology, 522-1, H\&R Technical Associates, Inc., Oak Ridge, Tennessee.

HSRCM-1, 1994, Hanford Site Radiological Control Manual, Pacific Northwest Laboratory, Richland, Washington.

IAEA, 1990, Advisory Material for the IAEA Regulations for the Safe Transport of Radioactive Material, Safety Series 37, 3rd Edition, International Atomic Energy Agency, Vienna, Austria.

Monroe, R. E., H. H. Woo, and R. G. Sears, 1984, Recommended Welding Criteria for Use in the Fabrication of Shipping Containers for Radioactive Materials, NUREG/CR-3019 (under Lawrence Livermore National Laboratory contract to the U.S. Nuclear Regulatory Commission), U.S. Nuclear Regulatory Commission, Washington, D.C.

NRC, 1991a, Fracture Toughness Criteria of Base Material for Ferritic Steel Shipping Cask Containment Vessels with a Maximum Wall Thickness of 4 Inches, Regulatory Guide 7.11, U.S. Nuclear Regulatory Commission, Washington, D.C.

NRC, 1991b, Fracture Toughness Criteria of Base Material for Ferritic Steel Shipping Cask Containment Vessels with a Wall Thickness Greater Than 4 Inches, But Not Exceeding 12 Inches, Regulatory Guide 7.12, U.S. Nuclear Regulatory Commission, Washington, D.C.

NRC, 1984, NRC IE Information Notice 84-72, September 10, U.S. Nuclear Regulatory Commission, Washington, D.C.

Schwarz, R. A., 1995, Neutron and Photon Baseline Source Terms for K-Basin Shie7ding, Internal Memo 8M730-LLC-95-011R1, Westinghouse Hanford Company, Richland, Washington.

WHC-CM-2-14, Hazardous Material Packaging and Shipping, Westinghouse Hanford Company, Richland, Washington.

WHC-CM-4-2, Quality Assurance Manual, Westinghouse Hanford Company, Richland, Washington.

WHC-CM-4-46, Safety Analysis Manual, Westinghouse Hanford. Company, Richland, Washington.

WHC-CM-6-1, Standard Engineering Practices, Westinghouse Hanford Company, Richl and, Washington.

WHC-CM-7-5, Environmental Compliance, Westinghouse Hanford Company, Richland, Washington.

WHC, 1995, WHC Occupational ALARA Program, WHC-IP-1043, Rev. 0, Westinghouse Hanford Company, Richland, Washington. 
WHC-SD-TP-PDC-030 Rev. 2

WHC, 1994, Report on Equivalent Safety for Transportation of Radioactive Materia7s, WHC-SD-TP-RPT-001, Rev 0, Westinghouse Hanford Company, Richl and, Washington. 


\author{
WHC-SD-TP-PDC-030 Rev. 2 \\ APPENDIX A \\ SAFETY CLASSIFICATION FOR THE K BASIN CASK \\ C. H. Huang \\ December 5, 1995
}

\title{
1.0 INTRODUCTION
}

Approximately 2,100 metric tons of unprocessed, irradiated nuclear fuel presently are stored in the $K$ Basins. To clean up this nuclear spent fuel in the $\mathrm{K}$ Basins, the fue 1 must be transported from the $100 \mathrm{~K}$ Basin Area to a Canister Storage Building (CSB) in the 200 East area. The shipping transport operation involves loading the irradiated fuel into the Multiple Canister Overpack (MCO) cask assembly at the $100 \mathrm{~K}$ Basin Area. The cask may be transported by either truck or train.

A transportation accident resulting in a fire is postulated.

In this document, the onsite and offsite doses were calculated to determine the safety classification for the system (the $K$ Basin cask) or components associated with the cask transport operations.

\subsection{PURPOSE}

The purpose of this document is to provide the safety classification for a packaging and transportation system (the $K$ Basin cask) to transport spent nuclear fuel within the boundary of the Hanford Site.

\subsection{SCOPE OF ANALYSIS}

This safety class analysis addresses the transportation of the $K$ Basin cask. In this analysis, only a bounding accident scenario will be anaiyzed.

\subsection{SOURCE TERM}

The worst-case source term for $\mathrm{N}$ Reactor fuel was specified by the customer.

In addition to the $\mathrm{N}$ fuel elements, a portion of the $\mathrm{N}$ Reactor fue 7 in both basins to be transported in the packaging system also is in the form of small fuel particles and radioactive corrosion products. 


$$
\text { WHC-SD-TP-PDC-030 Rev. } 2
$$

The fuel that is being stored in the $K$ Basins is stored in double barrelled canisters that contain up to $14 \mathrm{~N}$ Reactor fuel assemblies. The fuel is removed from these canisters and placed in baskets inside of the MCO. A maximum of 270 assemblies will be placed in these baskets.

\subsection{RADIOACTIVE INVENTORY}

The inventory in the baskets is contained within the MCO. The MCO acts as the primary container vessel. Table 1 shows the anticipated activity per unit mass, per assembly, and per cask. The cask contains a total of 270 assemblies.

Table 1. Worst-Case Source Term for N Reactor Fuel.

(provided by the customer)

\begin{tabular}{|c|c|c|c|c|c|c|c|}
\hline Isotope & $\begin{array}{l}\text { Curies } \\
\text { per MTU }\end{array}$ & $\begin{array}{l}\text { Curies per } \\
\text { single } \\
\text { assembly }\end{array}$ & $\begin{array}{l}\text { Curies per } \\
\text { MCO--270 } \\
\text { assemblies }\end{array}$ & Isotope & $\begin{array}{l}\text { Curies } \\
\text { per MTU }\end{array}$ & $\begin{array}{l}\text { Curies per } \\
\text { singte } \\
\text { assembly }\end{array}$ & $\begin{array}{l}\text { Curies per } \\
\text { MCO--270 } \\
\text { assemblies }\end{array}$ \\
\hline${ }^{3} \mathrm{H}$ & 38.8 & 0.91 & 246 & ${ }^{144} \mathrm{Ce}$ & 2.5 & 0.06 & 16 \\
\hline${ }^{55} \mathrm{Fe}$ & 6.8 & 0.16 & 43 & ${ }^{144} \mathrm{Pr}$ & 2.5 & 0.06 & 16 \\
\hline${ }^{60} \mathrm{Co}$ & 160.9 & 3.78 & 1020 & ${ }^{147} \mathrm{Pm}$ & $2,423.2$ & 56.9 & 15,363 \\
\hline${ }^{85} \mathrm{Kr}$ & 611.5 & 14.36 & 3,877 & ${ }^{151_{\mathrm{Sm}}}$ & 102.7 & 2.41 & 651 \\
\hline${ }^{90} \mathrm{Sr}$ & $7,893.2$ & 185.34 & 50,043 & ${ }^{154} \mathrm{Eu}$ & 192.3 & 4.51 & 1219 \\
\hline $90_{Y}$ & $7,893.2$ & 185.34 & 50,043 & ${ }^{155} \mathrm{Eu}$ & 33.4 & 0.79 & 212 \\
\hline${ }^{106} \mathrm{Ru}$ & 11.5 & 0.27 & 73 & ${ }^{238} \mathrm{Pu}$ & 147.3 & 3.46 & 934 \\
\hline $106_{\mathrm{Rh}}$ & 11.5 & 0.27 & 73 & ${ }^{239} \mathrm{Pu}$ & 152.1 & 3.57 & 964 \\
\hline${ }^{125} \mathrm{sb}$ & 99.1 & 2.33 & 628 & ${ }^{240} \mathrm{Pu}$ & 115 & 2.70 & 729 \\
\hline${ }^{125 \mathrm{~m}} \mathrm{Te}$ & 24.1 & 0.57 & 153 & ${ }^{241} \mathrm{Pu}$ & $9,139.9$ & 214.62 & 57,947 \\
\hline${ }^{134} \mathrm{cs}$ & 115 & 2.70 & 729 & ${ }^{241_{A n}}$ & 272.9 & 6.41 & 1730 \\
\hline${ }^{137} \mathrm{cs}$ & $10,734.9$ & 252.07 & 68,059 & ${ }^{244} \mathrm{~cm}$ & 39.9 & 0.94 & 253 \\
\hline $137 \mathrm{~m}_{\mathrm{Ba}}$ & $10,162.3$ & 238.63 & 64,429 & & & & \\
\hline
\end{tabular}

MCO = Multiple canister overpack.

MTU = Metric ton of uranium.

\subsection{ACCIDENT SCENARIOS/INITIATING EVENTS}

The bounding condition considered for the accident scenario is a fire accident.

The possible cause of fire accidents is that the truck fuel could catch fire due to traffic accidents.

In the accident postulated, all of the fuel in the $\mathrm{MCO}$ is assumed to be exposed and surrounded by fire. 


\subsection{RELEASE FRACTION}

An airborne release fraction (ARF) of $5.0 \times 10^{-3}$ (DOE 1994, pp. 4-37) is used to calculate the doses at the onsite and offsite receptor locations for the fire scenario. This release fraction was taken from DOE (1994) and is associated with oxidation of uranium. The $5 \times 10^{-3}$ was selected because it is the most conservative value. This release fraction is applied to all radionuclides present, except for cesium, ruthenium, and tellurium, which are considered semivolatile. The release fraction for ruthenium and tellurium was taken to be $1 \times 10^{-2}$ (DOE 1992, p. A-9). The release fraction for cesium was taken to be 0.09 (DOE 1994). The release fraction for krypton and tritium was taken to be 1.0 (DOE 1992, p. A-9).

The quantity of airborne radioactive material released from the fire is therefore equal to the activity of each radionuclide listed in Table 1 times the release fraction.

The worst-case source term for $\mathbf{N}$ Reactor fuel, adjusting for the airborne release fraction, is given in Table 2 .

Table 2. Worst-Case Source Term for $N$ Reactor Fuel.

\begin{tabular}{|c|c|c|c|}
\hline I sotope & Ci/Cask & I sotope & Ci/Cask \\
\hline $3_{\mathrm{H}}$ & $2.5 \mathrm{E}+2$ & ${ }^{144} \mathrm{Ce}$ & $8.0 \mathrm{E}-2$ \\
\hline${ }^{55} \mathrm{Fe}$ & $2.2 \mathrm{E}-1$ & ${ }^{144} \mathrm{Pr}$ & $8.0 \mathrm{E}-2$ \\
\hline${ }^{60} \mathrm{Co}$ & 5.1 & $147_{\mathrm{Pm}}$ & $7.7 \mathrm{E}+1$ \\
\hline${ }^{85} \mathrm{Kr}$ & $3.9 \mathrm{E}+3$ & $151_{\mathrm{Sm}}$ & 3.3 \\
\hline${ }^{90} \mathrm{Sr}$ & $2.5 \mathrm{E}+2$ & $154_{\mathrm{Eu}}$ & 6.1 \\
\hline${ }^{90}{ }_{\mathrm{Y}}$ & $2.5 \mathrm{E}+2$ & $155_{\mathrm{Eu}}$ & 1.1 \\
\hline $106{ }_{\mathrm{Ru}}$ & $7.3 \mathrm{E}-1$ & $238_{\mathrm{Pu}}$ & 4.7 \\
\hline $106_{\mathrm{Rh}}$ & $3.7 \mathrm{E}-1$ & $239_{\mathrm{Pu}}$ & 4.8 \\
\hline $1255_{\mathrm{Sb}}$ & 3.1 & $240_{\mathrm{Pu}}$ & 3.6 \\
\hline $125 \mathrm{~m}_{\mathrm{Te}}$ & 1.5 & $241_{\mathrm{Pu}}$ & $2.9 \mathrm{E}+2$ \\
\hline $134_{\mathrm{Cs}}$ & $6.6 \mathrm{E}+1$ & $241_{\mathrm{Am}}$ & 8.7 \\
\hline $137_{\mathrm{Cs}}$ & $6.1 \mathrm{E}+3$ & $244_{\mathrm{Cm}}$ & 1.3 \\
\hline $137 \mathrm{~m}_{\mathrm{Ba}}$ & $3.2 \mathrm{E}+2$ & & \\
\hline & & & \\
\hline
\end{tabular}

\subsection{METHODOLOGIES AND ASSUMPTIONS}

Acute maximum individual ground-level release doses for the onsite and offsite receptors were calculated using the computer code GENII version 1.485 (Napier et al. 1988). 
WHC-SD-TP-PDC-030 Rev. 2

\subsection{CODE DOCUMENTATION}

- GENII version $1.485(12 / 3 / 90)$

- GENII Default Parameter Values (28-Mar-90 RAP)

- Radionuc7ide Master Library (7/23/93 PDR)

- PNL Food Transfer Factor Library (7/19/93)

- External Dose Factor Library (8-May-90-RAP)

- Internal Dose Increments, PNL Solubilities (7/23/93 PDR)

- Joint Frequency Data: 100 Area, 10 m, Pasquill A-G (19831991 Average). The worst dose consequences would occur in the 100 Area.

GENII input files are attached in Appendix A.

\subsection{RESULTS}

The safety class for the K Basin cask transporting $N$ Reactor fuel assemblies was determined in accordance with the guidance provided in WHC-CM-4-46, 9.0, Rev. 0, "Assigning Safety Classes to Systems, Components and Structures." In the case of radioactive materials; the failure of a system or component that could result in an offsite public exposure in excess of 500 mrem effective dose equivalent is classified as Safety Class 1. The guidance for making a safety class determination for a facility or a system indicates that the safety classification is based upon the determination of consequences of potential accidents without the mitigation provided by engineered or administrative barriers. In addition, the entire inventories of hazardous materials allowed in the facility or the system are assumed to be present.

Atmospheric dispersion factor, $X / Q s$, for the onsite and offsite receptors were taken from Savino (1995). The onsite receptor is located $100 \mathrm{~m}$ from the source; the offsite receptor is $11,730 \mathrm{~m}$ west of the $\mathrm{K}$ Basins (current site boundary). For the proposed site boundary (see footnotes in Table 3 ), the maximum offsite receptor $X / Q$ value is $1.54 \mathrm{E}-02 \mathrm{~s} / \mathrm{m}^{3}$, which is associated with a receptor at $150 \mathrm{~m}$ in the northwest direction from the $100 \mathrm{~K} \mathrm{Area}$. The calculated values of $X / Q$ are given in Table 3 . for the onsite and offsite receptors. 
Table 3. The Values of $X / Q$ for the Onsite, Near Riverbank, and offsite Receptors

in the Worst Sector.

\begin{tabular}{|l|l|}
\hline \multicolumn{1}{|c|}{ Receptor } & \multicolumn{1}{|c|}{$/ \mathrm{Q}\left(\mathrm{s} / \mathrm{m}^{3}\right)$} \\
\hline Onsite $(100 \mathrm{~m} \mathrm{E})$ & $7.32 \mathrm{E}-02$. \\
\hline Near riverbank ${ }^{1}(150 \mathrm{NW})$ & $1.54 \mathrm{E}-02$ \\
\hline Offsite $(11.7 \mathrm{~km} \mathrm{~W})^{2}$ & $3.70 \mathrm{E}-05$ \\
\hline
\end{tabular}

${ }^{1}$ The proposed site boundary distance is the minimum distance from the area boundary of interest (i.e., $100 \mathrm{~K}$ or 200 East Area) to the proposed site boundary. The proposed site boundary assumes the site is bounded by Highway 240 on the west and the near riverbank on the north and east.

The current site boundary distance is the minimum distance from the area boundary of interest (i.e., $100 \mathrm{~K}$ or 200 East Area) to the existing site boundary.

The values of $X / Q$, as shown in Table 3 , are used as input data into the GENII code for dose calculations. The calculated doses for the onsite and offsite receptors are given in Table 4.

Table 4. The Calculated Doses for the Onsite, Near Riverbank, and offsite Receptors.

\begin{tabular}{|l|l|}
\hline \multicolumn{1}{|c|}{ Receptor } & \multicolumn{1}{|c|}{$\begin{array}{c}\text { Effective dose } \\
\text { equivalent (rem) }\end{array}$} \\
\hline Onsite $(100 \mathrm{~m} \mathrm{E})$ & $2.4 \mathrm{E}+05$ \\
\hline Near riverbank ${ }^{1}(150 \mathrm{~m} \mathrm{NW})$ & $4.9 \mathrm{E}+04$ \\
\hline Offsite $(11.7 \mathrm{~km} \mathrm{~W})^{2}$ & $1.2 \mathrm{E}+02$ \\
\hline
\end{tabular}

As shown in Table 4, the exposures to the public at a near riverbank receptor and an offsite receptor are $4.9 \times 10^{4}$ and $1.2 \times 10^{2}$ rem, respectively, which exceed the 500 mrem threshold limit for Safety class 1. Therefore, the $\mathrm{K}$ Basin cask loaded with $\mathrm{N}$ reactor fuel is classified as Safety Class 1. 


\subsection{REFERENCES}

DOE, 1992, Hazard Categorization and Accident Analysis Techniques for Compliance with DOE Order 5480.23, Nuclear Safety Analysis Reports, DOE-STD-1027-92, U.S. Department of Energy, Washington, D.C.

DOE, 1994, Airborne Release Fractions/Rates and Respirable Fractions for Nonreactor Nuclear Facilities, DOE-HDBK-3010-94, U.S. Department of Energy, Washington, D.C.

Hartmann, I., J. Nagy, and M. Jacobson, 1951, The Explosive Characteristics of $T i, \mathrm{Zr}, \mathrm{Th}, \mathrm{U}$ and Their Hydrides, U.S. Bureau of Mines Report 4835.

Napier, B. A., et al., 1988, GENII - The Hanford Environmental Radiation Dosimetry Software System, PNL-6484, Pacific Northwest Laboratory, Richland, Washington.

Peacock, H. B., 1992, Pyrophoricity of Uranium, WSRC-TR-92-106, Savannah River Laboratory, Aiken, South Carolina.

Savino, A. V., 1995, Preliminary Dose Consequence Study for the Hanford Interarea Protective Package Overpack (HIPPO), 8M400-AVS-95-007, Draft, Westinghouse Hanford Company, Richland, Washington.

WHC-CM-4-46, Nonreactor Facility Safety Analysis Manual, Westinghouse Hanford Company, Richland, Washington. 
WHC-SD-TP-PDC-030 Rev. 2

\section{APPENDIX A}

\section{GENII INPUT FILES}

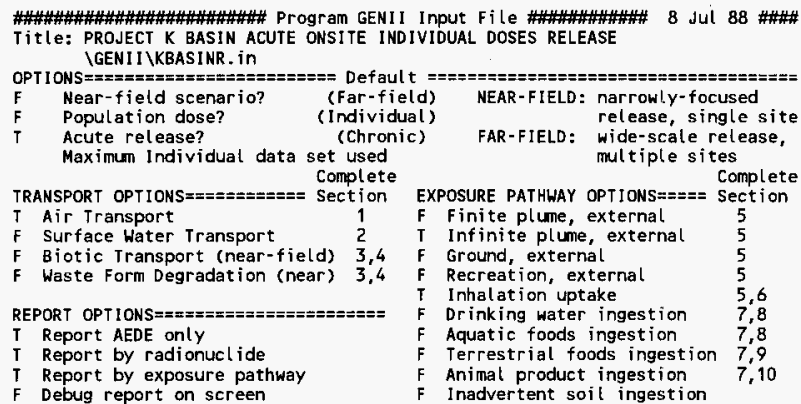

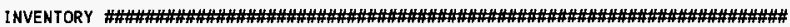

4 Inventory input activity units: (1-pCi $2-u C i \quad 3-m C i \quad 4-C i \quad 5-B q)$

0 Surface soil source units (1- m2 2- $\left.\mathrm{m}^{3} 3-\mathrm{kg}\right)$

Equilibrium question goes here

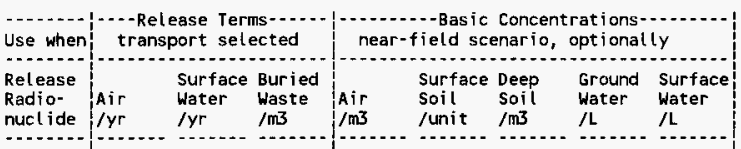

$\begin{array}{ll}\mathrm{H} & 2.5 \mathrm{E}+2\end{array}$

FE55 2.2E-1

$\cos 0 \quad 5.1$

KR85 $3.9 \mathrm{E}+3$

SR90 $2.5 \mathrm{E}+2$

Y $90 \quad 2.5 \mathrm{E}+2$

RU106 $7.3 \mathrm{E}-1$

SB125 3.1

TE125M 1.5

CS134 $6.6 \mathrm{E}+1$

CS137 $6.1 \mathrm{E}+3$

CE144 8.0E-2

PR $144 \quad 8.0 E-2$

PM147 7.7E+1

SM151 3.3

EU154 6.1

EU155 1.1

PU238 4.7

PU239 4.8

PU240 3.6

PU241 2.9E+2

AM241 8.7

CM244 1.3

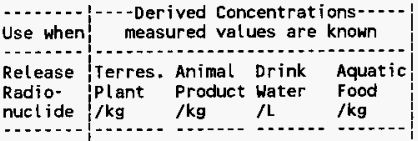


1 Intake ends after (yr)

50 Dose calc. ends after (yr)

0 Release ends after $(y r)$

0 No. of years of air deposition prior to the intake period

0 No. of years of irrigation water deposition prior to the intake period

FAR-FIELD SCENARIOS (IF POPULATION DOSE)

0 Definition option: 1 -Use population grid in file POP. IN

$0 \quad 2$-Use total entered on this line

MEAR-FIELD SCENARIOS

Prior to the beginning of the intake period: ( $y r)$

When was the inventory disposed? (Package degradation starts)

When was LoIC? (Biotic transport starts)

Fraction of roots in upper soil (top $15 \mathrm{~cm}$ )

Fraction of roots in deep soil

Manual redistribution: deep soil/surface soil dilution factor

Source area for external dose modification factor (m2)

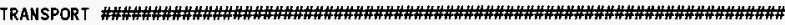

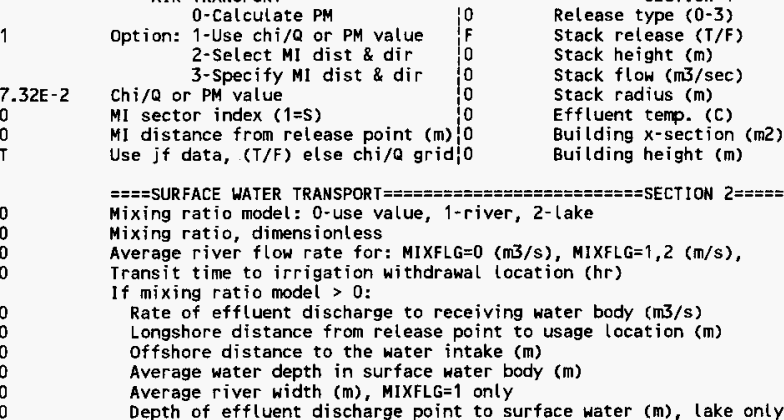

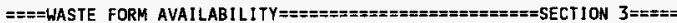
Waste form/package half life, (yr)

Waste thickness, (m)

Depth of soil overburden, $m$

$===$ BIOTIC TRANSPORT OF BURIED SOURCE===============SECTION $4=====$

Consider during inventory decay/buildup period $(T / F)$ ?

Consider during intake period (T/F)? 1-Arid non agricultural

Pre-Intake site condition...............

EXPOSURE

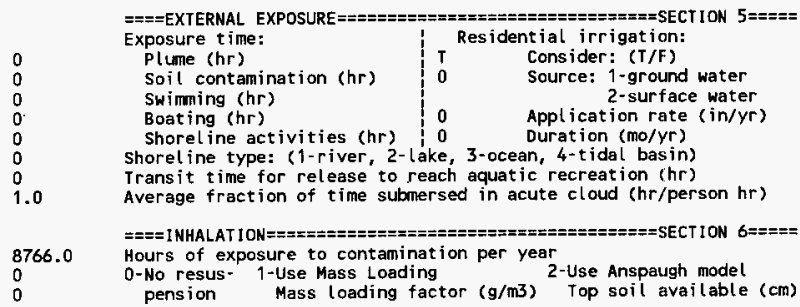




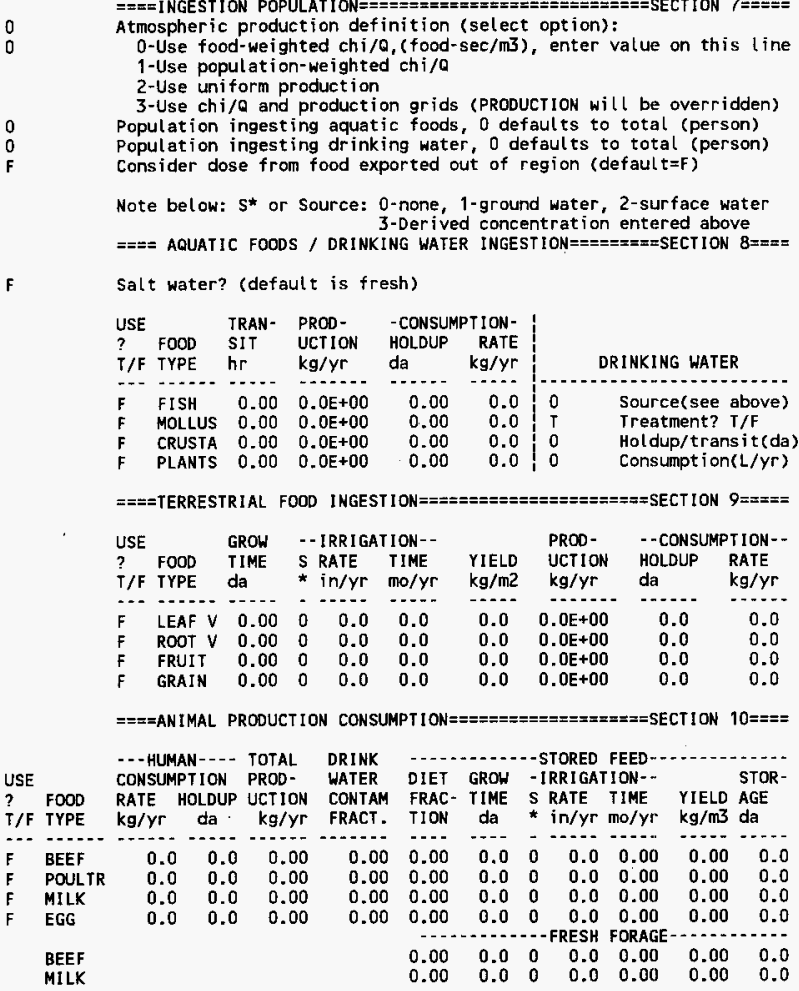




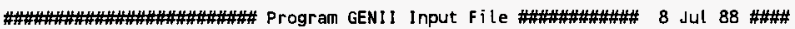
TitLE: PROJECT $K$ BASIN ACUTE OFFSITE INDIVIDUAL DOSES RELESAE \GENII \KBASNRFR. in

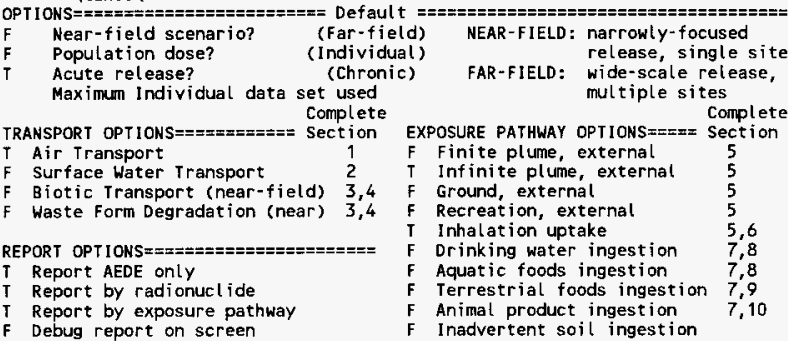

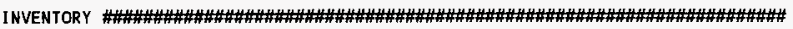

4 Inventory input activity units: (1-pCi 2-uCi $3-\mathrm{mCi} \quad 4-\mathrm{Ci}$ 5-Bq)

0 Surface soil source units (1- m2 2- $\left.\mathrm{m}^{3} 3-\mathrm{kg}\right)$

Equilibrium question goes here

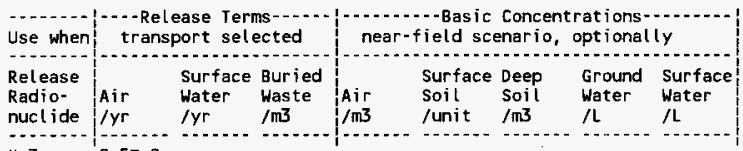

H $32.5 \mathrm{E}+2$

FE55 2.2E-1

Co60 5.1

KR85 3.9E+3

SR90 2.5E+2

Y $90 \quad 2.5 \mathrm{E}+2$

RU106 7.3E-1

SB125 3.1

TE125M 1.5

CS134 6.6E+1

CS137 6.1E+3

CE144 8.0E-2

PR144 8.0E-2

PM147 7.7E+1

SM151 3.3

EU154 6.1

EU155 1.1

PU238 4.7

PU239 4.8

PU240 3.6

PU241 2.9E+2

AM241 8.7

$\begin{array}{ll}\text { CM244 } & 1.3\end{array}$

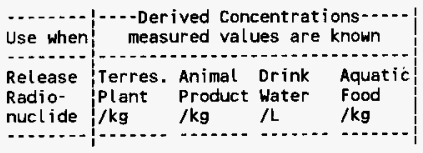

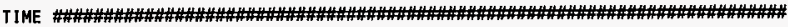

1 Intake ends after $(y r)$

50 Dose calc. ends after (yr)

0 Release ends after (yr)

0 No. of years of air deposition prior to the intake period

0 No. of years of irrigation water deposition prior to the intake period 
FAR-FIELD SCENARIOS (IF POPULATION DOSE)

0 Definition option: 1-Use population grid in file POP.IN

0 2-Use total entered on this line

NEAR-FIELD SCENARIOS

Prior to the beginning of the intake period: ( $y r)$

When was the inventory disposed? (Package degradation starts)

When was Lolc? (Biotic transport starts)

Fraction of roots in upper soil (top $15 \mathrm{~cm}$ )

Fraction of roots in deep soil.

Manual redistribution: deep soil/surface soil dilution factor

Source area for external dose modification factor (m2)

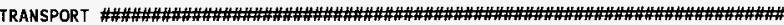

1

$1.54 E-2$
0
0
$T$

a

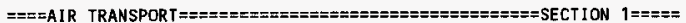

0 -Calculate PM 10 Release type $(0-3)$

Option: 1-Use chi/Q or PM value f Stack release (T/F)

2-Select MI dist \& dir $0 \quad$ stack height (m)

3-Specify MI dist \& dir $0 \quad$ stack flow $(\mathrm{m} 3 / \mathrm{sec})$

Chi/e or PA value

stack radius $(m)$

MI sector index (1=S) 0 Effluent temp. (C)

M] distance from release point (m) 0 Building $x$-section (m2)

Use jf data, (T/F) else chi/Q grid/0 Building height (m)

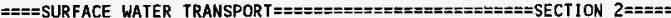

Mixing ratio model: 0 -use value, 1-river, 2-lake

Mixing ratio, dimensionless

Average river flow rate for: MIXFLG=0 $(\mathrm{m} 3 / \mathrm{s}), \operatorname{MIXFLG}=1,2(\mathrm{~m} / \mathrm{s})$,

Transit time to irrigation withdrawal location (hr)

If mixing ratio model $>0$ :

Rate of effluent discharge to receiving water body (m3/s)

Longshore distance from release point to usage location (m)

offshore distance to the water intake (m)

Average water depth in surface water body (m)

Average river width (m), MIXFLG=1 only

Depth of effluent discharge point to surface water (m), lake only

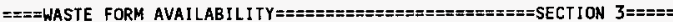
Waste form/package half life, (yr)

Waste thickness, (m)

Depth of soil overburden, in

$====B$ IOTIC TRANSPORT OF BUR IED SOURCE================SECTION $4====$

Consider during inventory decay/buildup period (T/F)?

Consider during intake period (T/F)? 1-Arid non agricultural

Pre-Intake site condition............. 2-Humid non agricultural

3-Agricultural

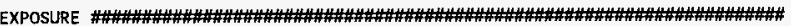

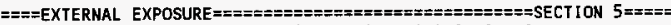

Exposure time:

Plume (hr)

T Residential irrigation: (T/F)

Soil contamination (hr) 0 Source: 1-ground water

Swiming $(h r) \quad 2$-sur face water

Boating (hr) Application rate (in/yr)

Shoreline activities (hr) 0 Duration (mo/yr)

shorel ine type: (1-river, 2-lake, 3-ocean, 4-tidal basin)

Transit time for release to reach aquatic recreation (hr)

1.0 Average fraction of time submersed in acute cloud (hr/person hr)

8766.0 Hours of exposure to contamination per year

0-No resus- 1-Use Mass Loading

2-Use Anspaugh model

pension

Mass Loading factor $\left(g / \mathrm{m}^{3}\right)$

Top soil available (cm)

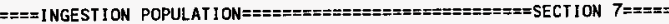

Atmospheric production definition (select option):

0 -Use food-weighted chi $/ Q$, (food-sec $\left./ \mathrm{m}^{3}\right)$, enter value on this line

1-Use population-weighted chi/Q

2-Use uniform production

3-Use chi/e and production grids (PRODUCTION will be overridden)

population ingesting aquatic foods, 0 defaults to total (person) 
0 Population ingesting drinking water, 0 defaults to total (person)

$F \quad$ Consider dose from food exported out of region (default $t=F$ )

Note below: $s^{*}$ or Source: 0-none, 1-ground water, 2-surface water 3-Derived concentration entered above

$====$ AQUATIC FOODS / DRINKING WATER INGESTION=========SECTION $8====$

Salt water? (default is fresh)

USE TRAN- PROD- -CONSUMPTION-

$?$ FOOD SIT UCTION HOLDUP RATE

T/F TYPE hr $\mathrm{kg} / \mathrm{yr}$ da $\mathrm{kg} / \mathrm{yr}$

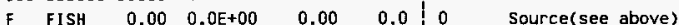

F MOLLUS $0.00 \quad 0.0 \mathrm{E}+00 \quad 0.00 \quad 0.0 \quad T \quad$ Treatment? T/F

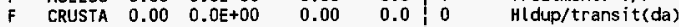

F PLANTS $0.00 \quad 0.0 E+00 \quad 0.00 \quad 0.0 \quad 0 \quad$ Consumpton( $\mathrm{l} / \mathrm{yr}$ )

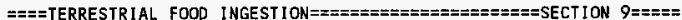

USE GROW --IRRIGAIION-- PROD- --CONSUMPTION--

? FOOD TIME S RATE TIME YIELD UCTION HOLDUP RATE

T/F TYPE da * in/yr mo/yr $\mathrm{kg} / \mathrm{m}_{2} \mathrm{~kg} / \mathrm{yr}$ da $\mathrm{kg} / \mathrm{yr}$

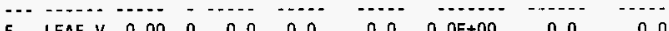

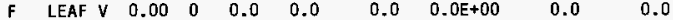

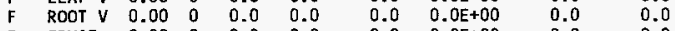

$\begin{array}{lllllllll}\text { F FRUIT } & 0.00 & 0 & 0.0 & 0.0 & 0.0 & 0.0 \mathrm{E}+00 & \mathbf{0 . 0} & \mathbf{0 . 0}\end{array}$

$\begin{array}{lllllllll}\text { F GRAIN } & 0.00 & 0 & 0.0 & 0.0 & 0.0 & 0.0 \mathrm{E}+00 & 0.0 & 0.0\end{array}$

====ANIMAL PRODUCTION CONSUMPTION========="==========SECTION 10====

\begin{tabular}{|c|c|c|c|c|c|c|c|c|c|c|c|c|}
\hline $\begin{array}{l}\text { USE } \\
? \\
\text { T/F }\end{array}$ & $\begin{array}{l}\text { FOOD } \\
\text { TYPE }\end{array}$ & $\begin{array}{l}-\cdot-\text { HUM } \\
\text { CONSUM } \\
\text { RATE } \\
\mathrm{kg} / \mathrm{yr}\end{array}$ & $\begin{array}{l}\text { AAN -... } \\
\text { APTION } \\
\text { HOLDUP } \\
\text { da }\end{array}$ & $\begin{array}{l}\text { TOTAL } \\
\text { PROD- } \\
\text { UCTION } \\
\mathrm{kg} / \mathrm{Yr}\end{array}$ & $\begin{array}{l}\text { DRINK } \\
\text { WATER } \\
\text { CONTAM } \\
\text { FRACI. }\end{array}$ & $\begin{array}{l}\text { DIET } \\
\text { FRAC- } \\
\text { TION }\end{array}$ & $\begin{array}{c}\text { GROW } \\
\text { TIME } \\
\text { da }\end{array}$ & $\begin{array}{l}2 \\
4 \\
-1\end{array}$ & $\begin{array}{l}\text { TORED } \\
\text { RRIGA } \\
\text { RATE } \\
\text { in/yr }\end{array}$ & $\begin{array}{l}\text { FEED-- } \\
\text { TION-- } \\
\text { TIME } \\
\mathrm{mo} / \mathrm{yr}\end{array}$ & $\begin{array}{l}\text { YIELD } \\
\mathrm{kg} / \mathrm{m3}\end{array}$ & $\begin{array}{l}\text { STOR- } \\
\text { AGE } \\
\text { da }\end{array}$ \\
\hline $\begin{array}{l}\mathbf{F} \\
\mathbf{F} \\
\mathbf{F} \\
\mathbf{F}\end{array}$ & $\begin{array}{l}\text { BEEF } \\
\text { POULTR } \\
\text { MILK } \\
\text { EGG }\end{array}$ & $\begin{array}{l}0.0 \\
0.0 \\
0.0 \\
0.0\end{array}$ & $\begin{array}{l}0.0 \\
0.0 \\
0.0 \\
0.0\end{array}$ & $\begin{array}{l}0.00 \\
0.00 \\
0.00 \\
0.00\end{array}$ & $\begin{array}{l}0.00 \\
0.00 \\
0.00 \\
0.00\end{array}$ & $\begin{array}{l}0.00 \\
0.00 \\
0.00 \\
0.00\end{array}$ & $\begin{array}{l}0.0 \\
0.0 \\
0.0 \\
0.0\end{array}$ & $\begin{array}{l}0 \\
0 \\
0 \\
0\end{array}$ & $\begin{array}{l}0.0 \\
0.0 \\
0.0 \\
0.0\end{array}$ & $\begin{array}{l}0.00 \\
0.00 \\
0.00 \\
0.00\end{array}$ & $\begin{array}{l}0.00 \\
0.00 \\
0.00 \\
0.00\end{array}$ & $\begin{array}{l}0.0 \\
0.0 \\
0.0 \\
0.0\end{array}$ \\
\hline & $\begin{array}{l}\text { BEEF } \\
\text { MILK }\end{array}$ & & & & & $\begin{array}{l}0.00 \\
0.00\end{array}$ & $\begin{array}{l}0.0 \\
0.0\end{array}$ & $\begin{array}{l}0 \\
0\end{array}$ & $\begin{array}{r}\text { RESH } \\
0.0 \\
0.0\end{array}$ & $\begin{array}{c}\text { FORAGE } \\
0.00 \\
0.00\end{array}$ & $\begin{array}{l}0.00 \\
0.00\end{array}$ & $\begin{array}{l}0.0 \\
0.0\end{array}$ \\
\hline
\end{tabular}




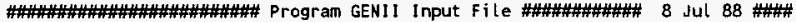
Title: PROJECT $K$ BASIN ACUTE OFFSITE INDIVIDUAL DOSES RELESAE IGENII \KBASNFR. in

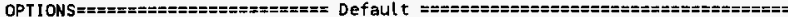

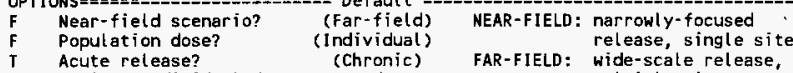
Maximum Individual data set used multiple sites

Complete Complete

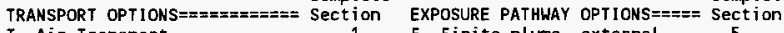

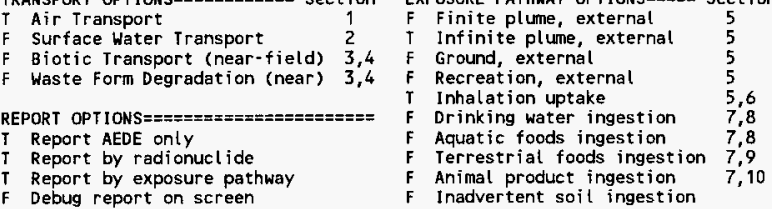

INVENTORY \#\#\#\#

4 Inventory input activity units: (1-pCi 2-uCi $3-\mathrm{mCi} \quad 4-\mathrm{Ci} \quad 5-\mathrm{Bq})$

0 Surface soil source units (1- $\left.\mathrm{m}^{2} \quad 2-\mathrm{m}^{3} \quad 3-\mathrm{kg}\right)$

Equilibrium question goes here

\begin{tabular}{|c|c|c|c|c|c|c|c|c|}
\hline se when & & oort sele & ected & & field sce & enari & opt 10 & \\
\hline Id & $\begin{array}{l}\text { Air } \\
/ y r\end{array}$ & $\begin{array}{l}\text { Surface } \\
\text { Water } \\
/ y r\end{array}$ & $\begin{array}{l}\text { Buried } \\
\text { Waste } \\
\text { / } \mathrm{m3}\end{array}$ & $\begin{array}{l}\text { Air } \\
/ \mathrm{mB}\end{array}$ & $\begin{array}{l}\text { Surface } \\
\text { Soil } \\
\text { /unit }\end{array}$ & $\begin{array}{l}\text { Deep } \\
\text { Soil } \\
/ \mathrm{m3}\end{array}$ & $\begin{array}{l}\text { Ground } \\
\text { Water } \\
\text { /L }\end{array}$ & $\begin{array}{l}\text { Surface } \\
\text { Water } \\
/ L\end{array}$ \\
\hline
\end{tabular}

H $32.5 \mathrm{E}+2$

FE55 2.2E-1

CO6O 5.1

KR85 $3.9 E+3$

SR90 2.5E+2

Y $90 \quad 2.5 \mathrm{E}+2$

RU106 7.3E-1

SB125 3.1

TE125M 1.5

CS134 6.6E+1

CS137 $6.1 \mathrm{E}+3$

CE144 8.0E-2

PR144 8.0E-2

PM147 7.7E+1

SM151 3.3

EU154 6.1

EU155 1.1

PU238 4.7

PU239 4.8

PU240 3.6

PU241 2.9E+2

AM241 8.7

CM244 1.3

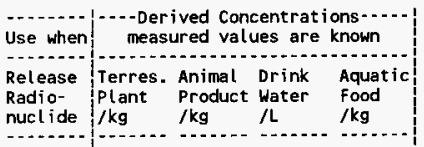

TIME

1 Intake ends after (yr)

50 Dose calc. ends after ( $y r$ )

0 Release ends after (yr)

0 No. of years of air deposition prior to the intake period

0 No. of years of irrigation water deposition prior to the intake period 


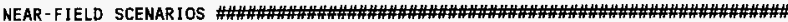

Prior to the beginning of the intake period: ( $y r$ )

When was the inventory disposed? (Package degradation starts)

When was Lolc? (Biotic transport starts)

Fraction of roots in upper soil (top $15 \mathrm{~cm}$ )

Fraction of roots in deep soil

Manual redistribution: deep soil/surface soil dilution factor

Source area for external dose modification factor (m2)

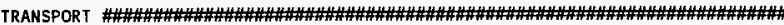

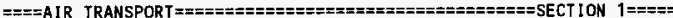

0 -Calculate PM 0 Release type $(0-3)$

Option: 1-Use chi/Q or PM value F stack release (T/F) 2-Select MI dist \& dir 0 stack height (m) 3-Specify MI dist \& dir 0 stack flow $(\mathrm{m} 3 / \mathrm{sec})$

3.70E-5 Chi/Q or PM value

Stack radius $(\mathrm{m})$

MI sector index (1=s) $\quad$ Effluent temp. (C)

MI distance from release point (Ni) 0 Building $x$-section (m2)

Use jf data, (T/F) else chi/0 grid:0 Building height (m)

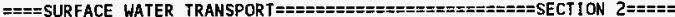

Mixing ratio model: 0-use value, 1-river, 2-lake

Mixing ratio, dimensionless

Average river flow rate for: MIXFLG $=0(\mathrm{m3} / \mathrm{s}), M I X F L G=1,2(\mathrm{~m} / \mathrm{s})$,

Transit time to irrigation withdrawal location (hr)

If mixing ratio model > 0:

Rate of effluent discharge to receiving water body $(\mathrm{m} 3 / \mathrm{s})$

Longshore distance from release point to usage location (m)

offshore distance to the water intake (m)

Average water depth in surface water body (m)

Average river width (m), MIXFLG=1 only

Depth of effluent discharge point to surface water (m), lake only

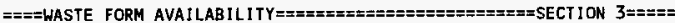
Waste form/package half life, (yr)

Waste thickness, (m)

Depth of soil overburden, m

$====B$ IOTIC TRANSPORT OF BUR IED SOURCE==10==

Consider during inventory decay/buildup period (T/F)?

Consider during intake period (T/F)? | 1 -Arid non agricultural

Pre-Intake site condition............ 2-Humid non agricultural

3-Agricul tural

EXPOSURE \#\#\#\#\#\#\#\#\#\#\#\#\#\#)

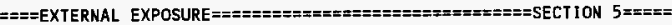

Exposure time:

$P$ lume (hr)

Residential irrigation:

Soil contamination (hr) $\quad 0 \quad$ Source: 1-ground water

Swifuning (hr) 2-surface water

Boating (hr) $\quad 0 \quad$ Application rate (in/yr)

Shorel ine activities ( $h r$ ) 0 Duration (mo/yr)

Shorel ine type: (1-river, 2-lake, 3-ocean, 4-tidal basin)

Transit time for release to reach aquatic recreation (hr)

Average fraction of time submersed in acute cloud (hr/person hr)

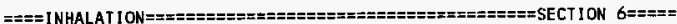

$\begin{array}{ll}8766.0 & \text { Hours of exposure to contamination per year } \\ 0 & 0 \text {-No resus- } 1 \text {-Use Mass Loading }\end{array}$

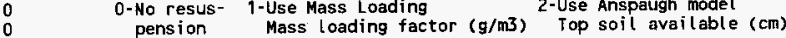

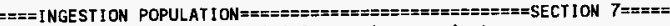

Atmospheric production definition (select option):

0 -use food-weighted chi $/ 0,($ food-sec $/ m 3)$, enter vatue on this line

1-Use population-weighted $\mathrm{ch} i / 0$

2-Use uniform. production

3-Use chi/Q and production grids (PRODUCTION will be overridden)

Population ingesting aquatic foods, 0 defaults to total (person) 
0 Population ingesting drinking water, 0 defaults to total (person)

F Consider dose from food exported out of region (default=F)

Note below: $\mathrm{S}^{*}$ or Source: 0-none, 1-ground water, 2-surface water 3-Derived concentration entered above $====$ AQUATIC FOODS / DRINKING WATER INGESTION========ESECTION $8====$

$\mathbf{F}$

Salt water? (default is fresh)

USE TRAN- PROD- - CONSUMPTION-

$?$ FOOD SIT UCTION HOLDUP RATE

T/F TYPE hr $\mathrm{kg} / \mathrm{yr}$ da $\mathrm{kg} / \mathrm{yr}$

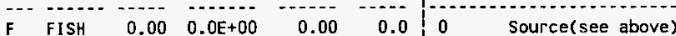

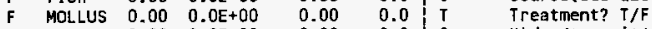

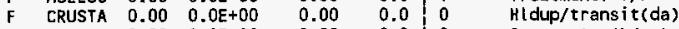

F PLANTS $0.00 \quad 0.0 E+00 \quad 0.00 \quad 0.0,0 \quad$ Consumpton(L/yr)

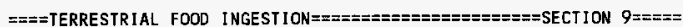

USE GROW --IRRIGATION--

? FOOD TIME S RATE TIME YIELD UCTION HOLDUP RATE

T/F TYPE da * in/yr mo/yr kg/m2 $\mathrm{kg} / \mathrm{yr}$ da $\mathrm{kg} / \mathrm{yr}$

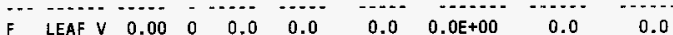

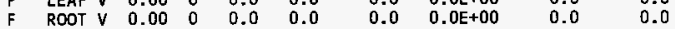

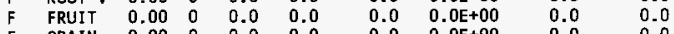

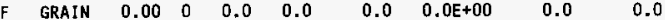

$====A N I M A L$ PRODUCTION CONSUMPTION===================5ECTION $10====$

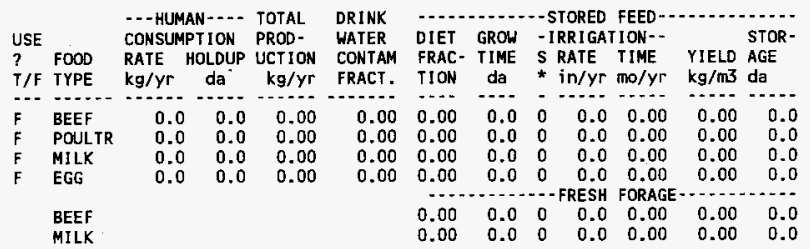

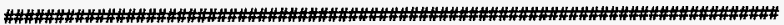


HEDOP REVIEW CHECKLIST

for

Radiological and Nonradiological Release Calculations

Document Reviewed: "SAFETY CLASSIFICATION FOR THE K BASIN CASK."

Submitted by: C. H. HUANG

Date Submitted: June 1, 1995

Scope of Review: Entire Document

YES NO* N/A

(4) [ ] [ ] 1. A detailed technical review and approval of the environmental transport and dose calculation portion of the analysis has been performed and documented.

$\circlearrowleft$ [ ] [ ] 2. Detailed technical review(s) and approval(s) of scenario and release determinations have been performed and documented.

[A [ ] [ ] 3. HEDOP-approved code(s) were used.

[] [] D] 4. Receptor locations were selected according to HEDOP

DA [ ] [ ] 5. All applicable environmental pathways and code options

were included and are appropriate for the calculations.

b [ ] [ ] 6. Hanford site data were used.

D. [ ] [ ] 8. The analysis is consistent with HEDOP recommendations.

9. Supporting notes, calculations, comments, comment resolutions, or other information is attached. (Use the "Page 1 of $X$ " page numbering format and sign and date each added page.)

W [ ] 10. Approval is granted on behalf of the Hanford Environmental Dose Overview Panel.

- All "NO" responses must be explained and use of nonstandard methods justified. D.A.Himes

COMMENTS (add additional signed and dated pages if necessary): 
WHC-SD-TP-PDC-030 Rev. 2

CHECKLIST FOR PEER REVIEH

Document Reviewed: C. H. Huang, "SAFETY CLASSIFICATION FOR THE K BASIN CASK," June 1, 1995.

Scope of Review: Entire Document

Yes No NA

[ ] [ ]. [X] * Previous reviews complete and cover analysis, up to scope of this review, with no gaps.

[๖] [ ] [ ] Problem completely defined.

[ [ [ ] Accident scenarios developed in a clear and logical manner.

QJ [ ] [ ] Necessary assumptions explicitly stated and supported.

[x] [ ] [ ] Computer codes and data files documented.

[x] [ [ ] [ [ ]

Data used in calculations explicitly stated in document.

Data checked for consistency with original source information as applicable.

[ ] [ ] [ $[$ ]

[ए] [ ] [ ]

[x] [ ] [ ]

[X] $\left[\begin{array}{lll}{[} & {[}\end{array}\right]$

Mathematical derivations checked including dimensional consistency of results.

Models appropriate and used within range of validity or use outside range of established validity justified.

Hand calculations checked for errors. Spreadsheet results should be treated exactly. the same as hand calculations.

Software input correct and consistent with document reviewed.

Software output consistent with input and with results reported in document reviewed.

K] [ ] ] $B_{3}$ Limits/criteria/guidelines applied to analysis results are appropriate and referenced. Limits/criteria/guidelines checked against references.

[ ] [ ] $[x]$ Safety margins consistent with good engineering practices.

$\left[\right.$ [ ] $\left[\begin{array}{l}{[} \\ {[}\end{array}\right]$ Conclusions consistent with analytical results and applicable limits.

K] [ ] [ ] Results and conclusions address all points required in the problem statement.

[ ] [ ] [X] Format consistent with appropriate NRC Regulatory Guide or other standards

[ ] [x] * Review calculations, comments, and/or notes are attached.

[X] [ ] [ ] Document approved.

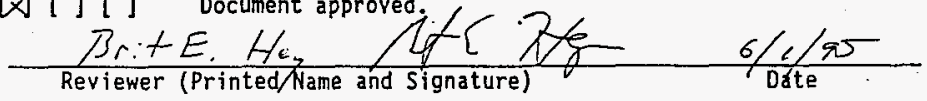




\section{WHC-SD-TP-PDC-030 Rev. 2}

This page intentionally left blank. 
WHC-SD-TP-PDC-030 Rev. 2

\section{APPENDIX B}

ONSITE SARP TABLE OF CONTENTS

PART A: DESCRIPTION AND OPERATIONS

1.0 INTRODUCTION

1.1 GENERAL INFORMATION

1.2 SYSTEM DESCRIPTION

1.3 REVIEW AND UPDATE CYCLES

2.0 PACKAGING SYSTEM

2.1 CONFIGURATION AND DIMENSIONS

2.2 MATERIALS OF CONSTRUCTION

2.3 MECHANICAL PROPERTIES OF MATERIALS

2.4 DESIGN AND FABRICATION METHODS

2.5 WEIGHTS AND CENTER OF GRAVITY

2.6 CONTAINMENT BOUNDARY

2.7 CAVITY SIZE

2.8 HEAT DISSIPATION

2.9 SHIELDING

2.10 LIFTING DEVICES

2.11 TIEDOWN DEVICES

3.0 PACKAGE CONTENTS

3.1 GENERAL DESCRIPTION

3.2 CONTENT RESTRICTIONS

3.2.1 Content Matrix

3.2.2 Radioactive Materials

3.2.3 Nonradioactive Materials

4.0 TRANSPORT SYSTEM

4.1 TRANSPORTER

4.2 TIEDOWN SYSTEM

4.3 SPECIAL TRANSFER REQUIREMENTS

5.0 ACCEPTANCE OF PACKAGING FOR USE

5.1 NEW PACKAGING

5.1.1 Acceptance Requirements

5.1.2 Inspection and Testing

5.1.3 Documentation

5.2 PACKAGING FOR REUSE

5.2.1 Acceptance Requirements

5.2.2 Inspection and Testing

5.2.3 Documentation

6.0 OPERATING REQUIREMENTS

6.1 GENERAL REQUIREMENTS

6.2 LOADING PACKAGE

6.3 UNLOADING PACKAGE

6.4 EMPTY PACKAGING 
7.0 QUALITY ASSURANCE REQUIREMENTS

7.1 INTRODUCTION

7.2 GENERAL REQUIREMENTS

7.3 ORGANIZATION

7.4 QUALITY ASSURANCE PLAN AND ACTIVITIES

7.4.1 Design Control

7.4.2 Procurement Control

7.4.3 Fabrication Control

7.4.4 Control and Inspection of testing

7.4.5 Maintenance Checks and Controls

7.4.6 Records and Document Control

7.5 SARP CONTROL SYSTEM

8.0 MAINTENANCE

8.1 GENERAL REQUIREMENTS

8.2 INSPECTION AND VERIFICATION SCHEDULES

8.3 RECORDS AND DOCUMENTATION

9.0 APPENDIX

9.1 DRAWINGS

PART B: PACKAGE EVALUATION

1.0 INTRODUCTION

1.1 SAFETY EVALUATION METHODOLOGY

1.2 EVALUATION SUMMARY AND CONCLUSIONS

1.3 APPENDIX

2.0 CONTENTS EVALUATION

2.1 CHARACTERIZATION

2.2 RESTRICTIONS

2.3 SIZE AND WEIGHT

2.4 CONCLUSIONS

2.5 APPENDIX

3.0 RADIOLOGICAL RISK EVALUATION

3.1 INTRODUCTION

3.2 RISK ACCEPTANCE CRITERIA

3.3 DOSE CONSEQUENCE ANALYSIS

3.4 PACKAGE FAILURE THRESHOLD ANALYSIS

3.5 ACCIDENT FREQUENCY ASSESSMENT

3.5.1 Approach

3.5.2 Accident Sequence Event Tree Analysis

3.6 RISK EVALUATION AND CONCLUSIONS

3.7 APPENDIX 
WHC-SD-TP-PDC-030 Rev. 2

4.0 CONTAINMENT EVALUATION

4.1 INTRODUCTION

4.2 CONTAINMENT SOURCE SPECIFICATION

4.3 NORMAL TRANSFER CONDITIONS

4.3.1 Conditions to be Evaluated

4.3.2 Containment Acceptance Criteria

4.3.3 Containment Mode1

4.3.4 Containment Calculations

4.4 ACCIDENT CONDITIONS

4.4.1 Conditions to be Evaluated

4.4.2 Containment Acceptance Criteria

4.4.3 Containment Mode1

4.4.4 Containment Calculations

4.5 CONTAINMENT EVALUATION AND CONCLUSIONS

4.6 APPENDIX

5.0 SHIELDING EVALUATION

5.1 INTRODUCTION

5.2 DIRECT RADIATION SOURCE SPECIFICATION

5.3 SUMMARY OF SHIELDING PROPERTIES OF MATERIALS

5.4 NORMAL TRANSFER CONDITIONS

5.4.1 Conditions to be Evaluated

5.4.2 Acceptance Criteria

5.4.3 Shielding Model

5.4.4 Shielding Calculations

5.5 ACCIDENT CONDITIONS

5.5.1 Conditions to be Evaluated

5.5.2 Acceptance Criteria

5.5.3 Shielding Model

5.5.4 Shielding Calculations

5.6 SHIELDING EVALUATION AND CONCLUSIONS

5.7 APPENDIX

6.0 CRITICALITY EVALUATION

6.1 INTRODUCTION

6.2 CRITICALITY SOURCE SPECIFICATION

6.3 SUMMARY OF CRITICALITY PROPERTIES OF MATERIALS

6.4 NORMAL TRANSFER CONDITIONS

6.4.1 Conditions To Be Evaluated

6.4.2 Acceptance Criteria

6.4.3 Criticality Model

6.4.4 Criticality Calculations

6.5 ACCIDENT CONDITIONS

6.5.1 Conditions To Be Evaluated

6.5.2 Acceptance Criteria

6.5.3 Criticality Model

6.5.4 Criticality Calculations

6.6 CRITICAL BENCHMARK EXPERIMENTS

6.6.1 Benchmark Experiments and Applicability

6.6.2 Details of Benchmark Calculations

6.6.3 Results of Benchmark Calculations

6.7 CRITICALITY EVALUATION AND CONCLUSIONS

6.8 APPENDIX 
WHC-SD-TP-PDC-030 Rev. 2

7.0 STRUCTURAL EVALUATION

7.1 INTRODUCTION

7.2 STRUCTURAL EVALUATION OF PACKAGE

7.2.1 Structural Design and Features

7.2.2 Mechanical Properties of Materials

7.2.3 Chemical and Galvanic Reactions

7.2.4 Size of Package and Cavity

7.2.5 Weights and Center of Gravity

7.2.6 Tamper-Indicating Feature

7.2.7 Positive Closure

7.2.8 Lifting and Tiedown Devices

7.2.9 Brittle Fracture

7.3 NORMAL TRANSFER CONDITIONS

7.3.1 Conditions to be Evaluated

7.3.2 Acceptance Criteria

7.3.3 Structural Model

7.3.4 Initial Conditions

7.3.4.1 Environmental Heat Loading

7.3.4.2 Maximum Thermal and Pressure Stresses

7.3.4.3 Structural Evaluations and Conclusions

7.4 ACCIDENT CONDITIONS

7.4.1 Conditions to be Evaluated

7.4.2 Acceptance Criteria

7.4.3 Structural Model

7.4.4 Initial Conditions

7.4.4.1 Environmental Heat Loading

7.4.4.2 Maximum Therma1 and Pressure Stresses

7.5 APPENDIX

7.4.4.3 Structural Evaluation and Conclusions

8.0 THERMAL EVALUATION

8.1 INTRODUCTION

8.2 THERMAL SOURCE SPECIFICATION

8.3 SUMMARY OF THERMAL PROPERTIES OF MATERIALS

8.4 THERMAL EVALUATION FOR NORMAL TRANSFER CONDITIONS

8.4.1 Conditions to be Evaluated

8.4.2 Acceptance Criteria

8.4.3 Thermal Model

8.4.4 Thermal Analysis

8.4.4.1 Internal Temperatures

8.4.4.2 Maximum Surface Temperatures

8.5 THERMAL EVALUATION FOR ACCIDENT CONDITIONS

8.5.1 Conditions to be Evaluated

8.5.2 Acceptance Criteria

8.5.3 Package Conditions and Environment

8.5.4 Thermal Model

8.5.5 Thermal Analysis

8.5.5.1 Internal Temperatures

8.5.5.2 Maximum Surface Temperatures

8.6 THERMAL EVALUATION AND CONCLUSIONS

8.7 APPENDIX 
WHC-SD-TP-PDC-030 Rev. 2

9.0 PRESSURE AND GAS GENERATION EVALUATION

9.I GAS GENERATION

9.2 PACKAGE PRESSURE

9.3 APPENDIX

10.0 PACKAGE TIEDOWN SYSTEM EVALUATION

10.1 SYSTEM DESIGN

10.2 ATTACHMENTS AND RATINGS

10.3 APPENDIX (CALCULATIONS) 


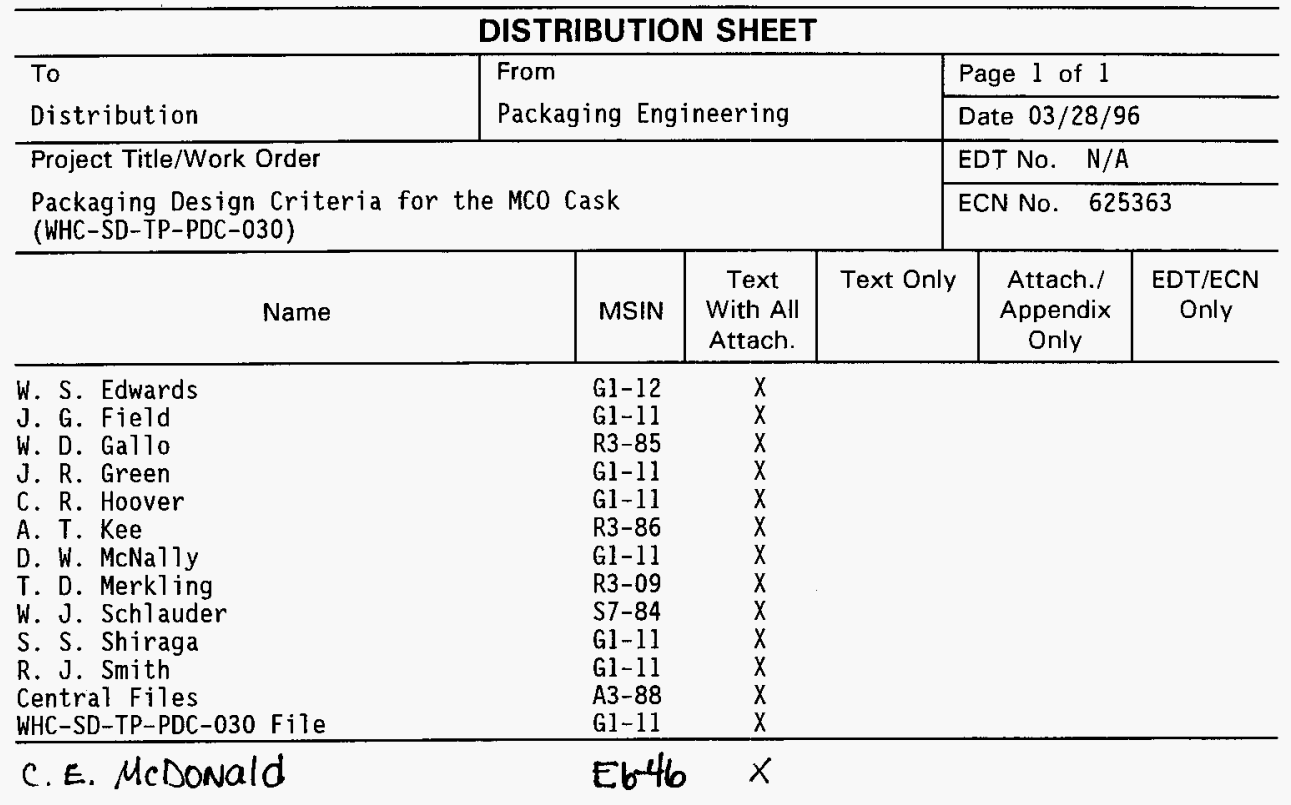

